\title{
Nitrogen use efficiency in rapeseed. A review
}

\author{
Anne-Sophie Bouchet ${ }^{1} \cdot$ Anne Laperche $^{2} \cdot$ Christine Bissuel-Belaygue $^{2}$ • \\ Rod Snowdon ${ }^{3} \cdot$ Nathalie Nesi $^{1} \cdot$ Andreas Stahl $^{3}$
}

Accepted: 10 May 2016 / Published online: 2 June 2016

(C) INRA and Springer-Verlag France 2016

\begin{abstract}
Mineral nitrogen fertilization has improved crop yield over the last century but has also caused air and water pollution. Reduction of nitrogen inputs and maintaining high yields are therefore essential to ensure a more sustainable agriculture. Improving the nitrogen use efficiency (NUE) of crops is therefore needed. Rapeseed, Brassica napus, depends on nitrogen fertilization due to its low NUE, with the ratio of plant nitrogen content to nitrogen supplied often not exceeding $60 \%$. Here, we review the major phenotypic traits associated with NUE in B. napus, with special emphasis on winter oilseed rape. We discuss the genetic diversity available and potential breeding strategies. The major points are the following: (1) rapeseed seed yield elaboration is complex, with overlapping phases of nitrogen uptake and remobilization during the crop cycle; (2) traits related to nitrogen uptake, such as root length and the amount of nitrogen absorbed after flowering, and traits related to nitrogen remobilization, such as the "staygreen" phenotype, have been identified as possible levers to improve NUE in rapeseed; (3) a substantial body of studies investigating the genetic control of NUE traits have already published and potential candidate genes identified; and (4)
\end{abstract}

Anne-Sophie Bouchet and Andreas Stahl contributed equally to this work.

Andreas Stahl

andreas.stahl@agrar.uni-giessen.de

1 INRA, UMR 1349 Institute for Genetics, Environment and Plant Protection, Domaine de la Motte, 35650 le Rheu, France

2 AGROCAMPUS OUEST, UMR 1349 Institute for Genetics, Environment and Plant Protection, Domaine de la Motte, 35650 le Rheu, France

3 Department of Plant Breeding, IFZ Research Center for Biosystems, Land Use and Nutrition, Justus Liebig University, Heinrich-Buff-Ring 26-32, 35392 Giessen, Germany rapeseed genetic diversity may be enriched by exploiting interpopulation genetic variation and the closely related gene pools of Brassica rapa and Brassica oleracea.

Keywords Brassica napus - Genetic diversity · Genomic selection · Nitrogen losses $\cdot$ Nitrogen remobilization · Nitrogen uptake efficiency $(\mathrm{NUpE}) \cdot$ Nitrogen utilization efficiency $(\mathrm{NUtE}) \cdot$ Yield

\section{Contents}

1. Introduction

2. Rapeseed shows a low apparent nitrogen use efficiency 2.1. Plant growth, nitrogen absorption, and yield elaboration make a complex story in winter rapeseed

2.2. There is scope to improve nitrogen use efficiency in rapeseed by building on existing genetic diversity

3. Factors related to nitrogen absorption and remobilization show genetic diversity in rapeseed

3.1. Seed yield is a good indicator of nitrogen use efficiency in rapeseed

3.2. Nitrogen uptake efficiency must be improved to maintain a high preanthesis plant nitrogen pool

3.3. The post-anthesis nitrogen balance between source organs and sink organs needs optimization

3.3.1. Following the senescence process in rapeseed 3.3.2. The "stay-green" phenotype may offer an opportunity for improvement of source-sink relationships

3.3.3. Nitrogen remobilization efficiency in rapeseed 3.4. Defining the ideotype of a nitrogen-efficient rapeseed

4. Advances in breeding for nitrogen-efficient rapeseed with optimized oil yield 
4.1. Breeding strategies must be oriented to genotypeby-environment interactions

4.2. Identification and characterization of nitrogen efficiency loci in rapeseed

4.2.1. Genetic control of traits related to seed yield

4.2.2. Genetic control of traits related to nitrogen uptake efficiency

4.2.3. Genetic control of traits related to nitrogen utilization efficiency

5. Future directions for genetic improvement of nitrogen use efficiency

5.1. Taking advantage of heterosis

5.2. Predicting rapeseed genotypic values

5.3. Phenotyping for nitrogen use efficiency

6. Conclusion

7. Acknowledgments

8. References

\section{Introduction}

In the past century, the invention and up-scaling of the Haber-Bosch process for manufacturing mineral nitrogen (N) fertilizers and the application of these fertilizers to modern agriculture have been crucial in achieving the high yield levels that are possible in today's agricultural production. However, the impact of nitrogen fertilizers on the environment has not always been positive (Tilman et al. 2002). Although progress has been made to optimize $\mathrm{N}$ fertilization, more than half of the worldwide $\mathrm{N}$ applied to crops is currently lost into the environment (Lassaletta et al. 2014). Noteworthy, amounts of $\mathrm{N}$ are not removed from fields during harvesting and escape from the agricultural production system through run-off, nitrate leaching, or as volatile nitrous oxide or ammonia, causing environmental damage (Billen et al. 2013). Moreover, mineral fertilizer production itself depends significantly on fossil energy, leading to additional greenhouse gas emissions and rising fertilizer costs. In addition, in the last 2 decades, especially in western European countries, overall crop yield increases have become partially decoupled from $\mathrm{N}$ fertilizer inputs (Conant et al. 2013; Lassaletta et al. 2014) and increases in $\mathrm{N}$ fertilization have led to relatively low gains in seed yield.

Increasing population levels and per capita consumption will require further significant gains in production to meet food and nonfood demand, but such gains will also impact the environment (Tilman et al. 2002). Reducing N inputs while maintaining high seed yield levels is therefore essential to ensuring sustainable agriculture in the future. This challenge must be approached not only at the agro-economic scale with the optimization of crop rotations, the use of sensor-based adjustments to fertilizer application, and a well-dosed integration of crops and livestock systems (Lassaletta et al. 2014) but also through the improvement of the intrinsic nitrogen use efficiency (NUE) of the crops themselves (Hirel et al. 2007).

A basic definition of NUE was given by Moll et al. (1982) — NUE is the seed yield that is produced per unit of available N. Total NUE may be divided into two components: (1) nitrogen uptake efficiency (NUpE), which describes the ability of the plant to capture $\mathrm{N}$ from the soil, and (2) nitrogen utilization efficiency (NUtE), the ability to utilize the absorbed $\mathrm{N}$ to produce seeds (Moll et al. 1982). At the plant level, nitrogen uptake efficiency incorporates trait effects such as root morphology and transporter activity, while nitrogen utilization efficiency is the result of all processes that contribute to the capacity of the plant to assimilate and remobilize $\mathrm{N}$ into the seeds (also referred to as nitrogen remobilization efficiency; Masclaux-Daubresse et al. 2010).

Although the definition of NUE is well established, its estimation is more complex, since this variable can be approached at different levels (previously reviewed by Good et al. (2004), Rathke et al. (2006), and Han et al. (2015)). Agronomic nitrogen use efficiency may be considered as the direct increase in seed yield per additional unit of $\mathrm{N}$ fertilizer (Good et al. 2004; Rathke et al. 2006). Physiological nitrogen use efficiency, on the other hand, is calculated as the nitrogen/ carbon balance in the shoots at harvest, determined by measuring the relationship between the biomass and the $\mathrm{N}$ content of the shoots (Good et al. 2004). Finally, for determination of intra-plant $\mathrm{N}$ allocation, $\mathrm{N}$ flux measurements based on isotope labeling techniques $\left({ }^{15} \mathrm{~N}\right)$ allow precise assessment of $\mathrm{N}$ dynamics throughout a plant's organs. While several publications have dealt with nitrogen use efficiency in general (Moll et al. 1982; Good et al. 2004; Fageria and Baligar 2005; Hirel et al. 2007; Xu et al. 2012; Vincourt 2014; Han et al. 2015) or have focused on special issues such as root-based approaches (Garnett et al. 2009), here, we will focus on nitrogen use efficiency in rapeseed (Brassica napus L.).

Rapeseed is a crop of major economic importance, mainly grown for its oil-rich seeds (Fig. 1). The seeds are used for human consumption as well as for industrial purposes, and the seedcake serves as an important protein source in livestock feeding (Berrocoso et al. 2015). Rapeseed is the third most important worldwide oil crop, behind soybean and palm oil. Over a 10-year period (2004-2013), rapeseed was produced on $30.94 \mathrm{M}$ ha worldwide, mainly in Canada (6.53 M ha), China (6.96 M ha), the European Union (7.75 M ha), Australia (1.75 M ha), and the USA $(0.48 \mathrm{M} \mathrm{ha})$. Within the European Union, France (1.43 M ha) and Germany $(1.40 \mathrm{M} \mathrm{ha})$ are the countries with the biggest oilseed rape production area (Food and Agriculture Organization of the United Nations 2013). Oilseed rape has a high value in crop rotation, exerting a strong positive influence on yields of subsequent cereals such as wheat (Christen et al. 1992) and barley (Christen and Sieling 1993). However, rapeseed production requires high inputs compared to other crops, particularly $\mathrm{N}$ 
Fig. 1 Winter oilseed rape from autumn to harvest. Pictures of winter oilseed rape taken in autumn (a), in spring (b), with a detail of one floral spike (c), and before harvest (d). A sample of seeds (e)

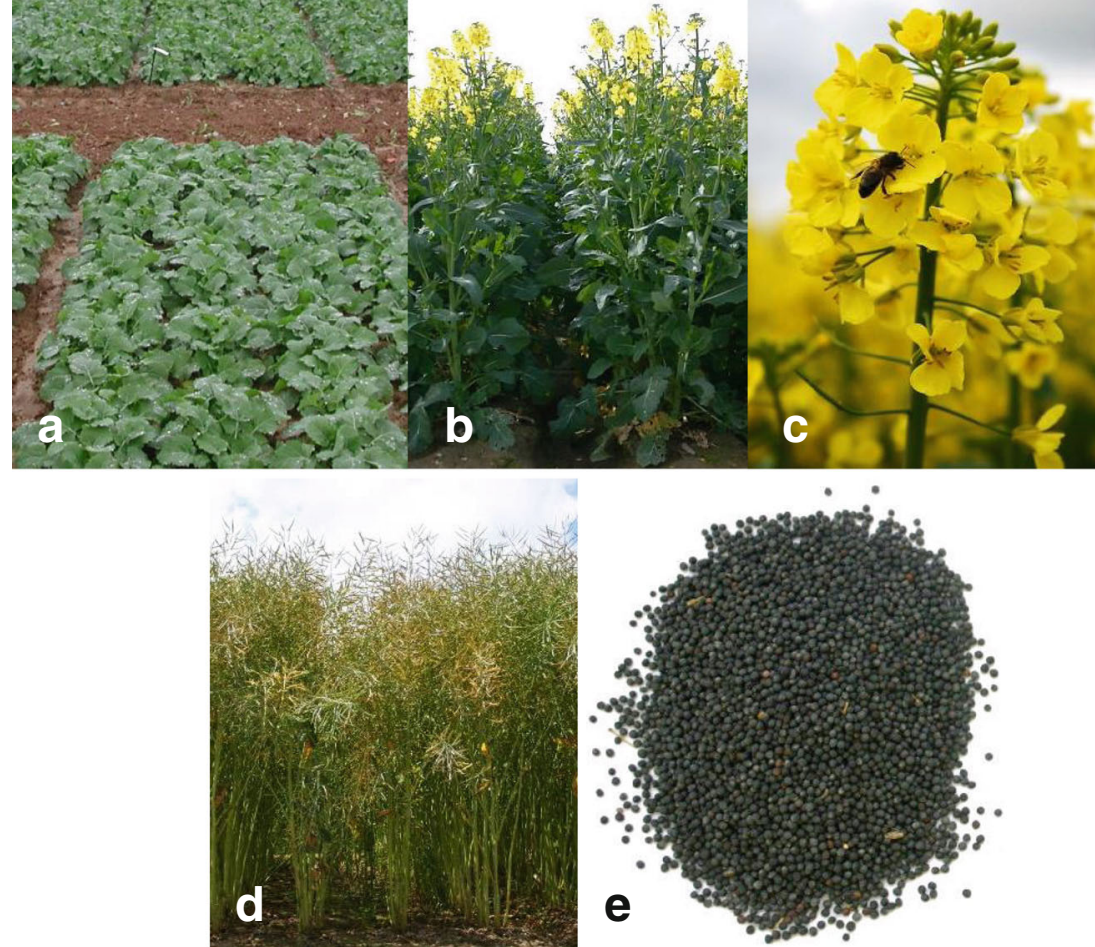

inputs (Rathke et al. 2005). Indeed, despite its capacity to absorb $\mathrm{N}$ from the soil during the autumn, which allows its use as a catch crop, rapeseed is often described as a crop with poor $\mathrm{N}$-efficiency and low seed production per unit $\mathrm{N}$ applied, which is around half that for cereals (Sylvester-Bradley and Kindred 2009). Improving the NUE of rapeseed is therefore crucial to ensure the competitiveness of this crop at agronomic, environmental, and economic levels.

In this article, we review aspects of NUE improvement with special emphasis on winter oilseed rape. We outline crucial elements of the physiological $\mathrm{N}$ dynamics of rapeseed throughout the crop cycle that need to be considered during research and breeding, and we connect them with the potential genetic diversity available in the species. We then discuss the possible improvement of NUE in rapeseed through plant breeding and the use of new genetic, genomic, and phenotyping technologies and information.

\section{Rapeseed shows a low apparent nitrogen use efficiency}

\subsection{Plant growth, nitrogen absorption, and yield elaboration make a complex story in winter rapeseed}

Seed yield per unit area is a complex trait that results from a combination of several components including plant density, the number of branches per plant, pod number per branch, seed number per pod, and single-seed weight (Diepenbrock
2000). Sequential determination of the yield components allows us to divide the rapeseed crop cycle into two overlapping phases: the establishment of the yield potential on the one hand and the expression of the yield potential on the other (Fig. 2).

During the vegetative growth phase in the autumn and winter, the dynamics of leaf area index (LAI) depend mainly on radiation interception and radiation use efficiency. Soil N availability also affects the leaf area index and depends on the pedo-climatic conditions: In temperate climates, soil $\mathrm{N}$ mineralization may be enough to cover the plant's $\mathrm{N}$ needs during autumn, but in colder areas, $\mathrm{N}$ fertilization may be needed. The root system develops quickly after seedling emergence, and mineral $\mathrm{N}$ is efficiently absorbed from the soil and incorporated into the vegetative biomass. For instance, rapeseed shows high nitrogen uptake efficiency in the early stages, with up to $100 \mathrm{~kg} \mathrm{~N}^{-1}$ being absorbed. This makes it a valuable catch crop during autumn (Rossato et al. 2001). Plant biomass increases dramatically over this first period. Simultaneously, $\mathrm{N}$ is remobilized from older to younger leaves due to sequential senescence, which promotes the initiation of foliar primordia as early as the end of autumn. As a consequence, the numbers of branches, photosynthetic leaves, flowers, and ovules are partly determined before the end of winter (Fig. 2). This in turn predetermines the final seed number per square meter, a variable that is highly correlated with seed yield. Nitrogen stress during autumn may therefore negatively affect the final yield. During winter, a part of the leaf area produced during this first period can be destroyed by freezing, leading to 


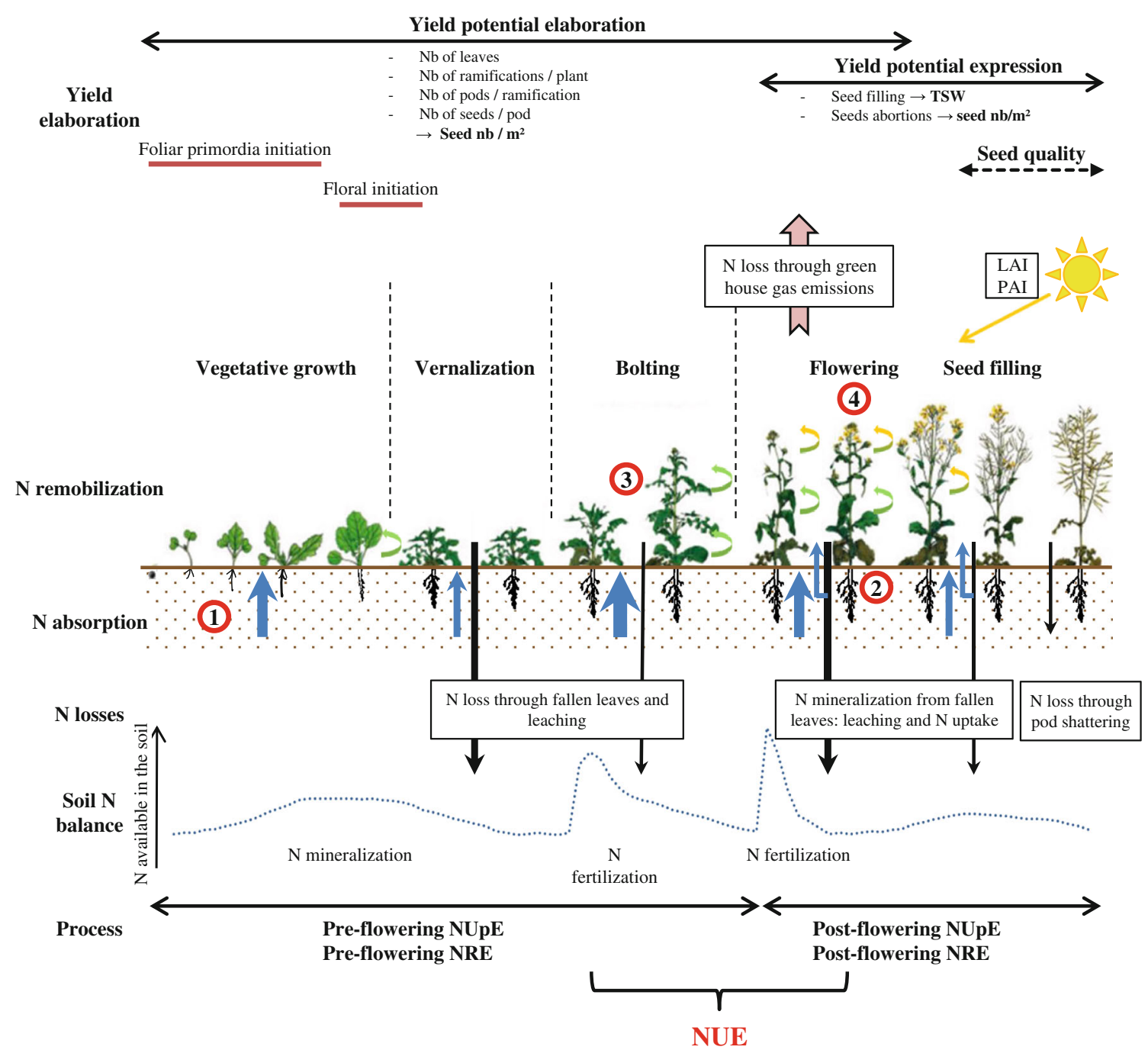

Fig. 2 Rapeseed $\mathrm{N}$ dynamics over the crop cycle. The figure depicts the interconnected relationships between plant growth, $\mathrm{N}$ dynamics, and yield elaboration over the crop cycle. $\mathrm{N}$ uptake is represented by blue arrows whose width indicates the relative amount of $\mathrm{N}$ absorbed at a given time point. $\mathrm{N}$ losses are shown with black arrows whose width indicates the relative amount of $\mathrm{N}$ lost at a given time point. The critical stages for the final establishment of nitrogen use efficiency (NUE) are

important $\mathrm{N}$ losses of 2-3.5 \% of the fallen leaves' dry weight (Malagoli et al. 2005a).

A new leaf area index is generated during the spring from the beginning of stem elongation to flowering. Soil $\mathrm{N}$ availability during spring development thus greatly affects leaf area index expansion and duration. During this period, $\mathrm{N}$ is actively remobilized from senescing leaves to younger leaves and stems (sequential senescence) and then to pods and seeds (monocarpic senescence) (Fig. 2). From the flowering stage onward, leaves are no longer produced, and the onset of senescence occurs quickly, with leaves showing different remobilization ability depending upon their position on the main stem (Malagoli et al. 2005a). In parallel, photosynthetic activity is partly ensured by the pod area index. In addition, the $\mathrm{N}$ noted as follows: preflowering nitrogen uptake efficiency (NUpE) and sequential nitrogen remobilization efficiency (NRE) (1); post-flowering nitrogen uptake efficiency (NUpE) (2); sequential and monocarpic NRE during the flowering and seed filling periods (3); and the interactions between NUE, leaf area index (LAI), and pod area index (PAI) (4). Thousand seed weight (TSW)

pool is also maintained through $\mathrm{N}$ reabsorption from leaves that have fallen during autumn, with an uptake efficiency that can reach $40 \%$ of the $\mathrm{N}$ content of the fallen leaves (Dejoux et al. 2000).

Nevertheless, the ratio of plant $\mathrm{N}$ content to supplied $\mathrm{N}$ does not usually exceed 50 to $60 \%$ in rapeseed (Malagoli et al. 2005a). As a consequence, a major problem is the large $\mathrm{N}$ surplus, which represents a significant shortfall for farmers and has negative environmental impacts. Breeding for $\mathrm{N}$ efficient rapeseed varieties is therefore a key objective for improving the economic and environmental competitiveness of the crop. As shown in Fig. 2, breeders must investigate a number of critical processes in order to identify and select for optimal $\mathrm{N}$ dynamics and plant development throughout the 
crop cycle. These include (1) preflowering nitrogen uptake efficiency and nitrogen remobilization efficiency, to ensure the establishment of the yield potential, (2) post-flowering nitrogen uptake efficiency, to maintain an $\mathrm{N}$ pool in the plant during the seed filling stage, (3) the nitrogen remobilization efficiency associated with the sequential and monocarpic senescence processes from flowering onwards, to develop the crop yield potential, and (4) the interactions between nitrogen balance and carbon balance, involving photosynthetic variables such as leaf area index, pod area index, and radiation use efficiency.

\subsection{There is scope to improve nitrogen use efficiency in rapeseed by building on existing genetic diversity}

Brassica napus L. $(2 n=4 x=38$, AACC) resulted from a recent spontaneous interspecific cross between Brassica rapa $(2 n=2 x=20, \mathrm{AA})$ and Brassica oleracea $(2 n=2 x=18, \mathrm{CC})$ (U 1935). The short domestication history of this species and the concentrated breeding efforts made during the 1970s to improve the quality of its oil led to a reduction in the genetic diversity of modern rapeseed (Hasan et al. 2005). In addition, rapeseed exhibits strong eco-geographical differentiation into spring and winter forms, with the former being commonly grown in northern latitudes and in Australia, whereas the latter are primarily cultivated in Western Europe (Bus et al. 2011).

Inbred varieties dominated rapeseed production until the early part of this century, meaning that genetic diversity for NUE has been specifically implemented in inbred line breeding. Different inbred lines grown under contrasting N nutrition levels typically exhibit three kinds of genotypic responses, namely (1) inefficient nonresponding genotypes that show low yields in both limited nitrogen $(\mathrm{N}-)$ and optimal nitrogen $(\mathrm{N}+)$ conditions, (2) inefficient responding genotypes with high yields in $\mathrm{N}+$ conditions but poor yields in $\mathrm{N}-$ conditions, (3) efficient responding genotypes that show high yields in both $\mathrm{N}-$ and $\mathrm{N}+$ conditions, and (4) efficient nonresponding genotypes that are superior under $\mathrm{N}-$ but under average under $\mathrm{N}+$ conditions (Fig. 3).

The switch to the near-exclusive breeding of F1 hybrid rapeseed varieties during the past decade has provided new genetic combinations that can be exploited for NUE improvement. For instance, Kessel et al. (2012) compared the seed yield responses of modern cultivars, hybrids, synthetic B. napus accessions, and old cultivars with changes in $\mathrm{N}$ conditions. That study found that selection for high yields indirectly enhanced NUE and that hybrids were the most productive genotypes whatever the $\mathrm{N}$ nutrition conditions.

Several studies have already explored the genetic diversity of N-related rapeseed traits under field and controlled conditions, in both spring (Yau and Thurling 1986; Svečnjak and Rengel 2005, 2006; Balint et al. 2008a) and winter cultivars (Schulte auf'm Erley et al. 2007; Berry et al. 2010; Schulte
Seed yield in

$\mathrm{N}+$ condition $(\mathrm{t} / \mathrm{ha})$

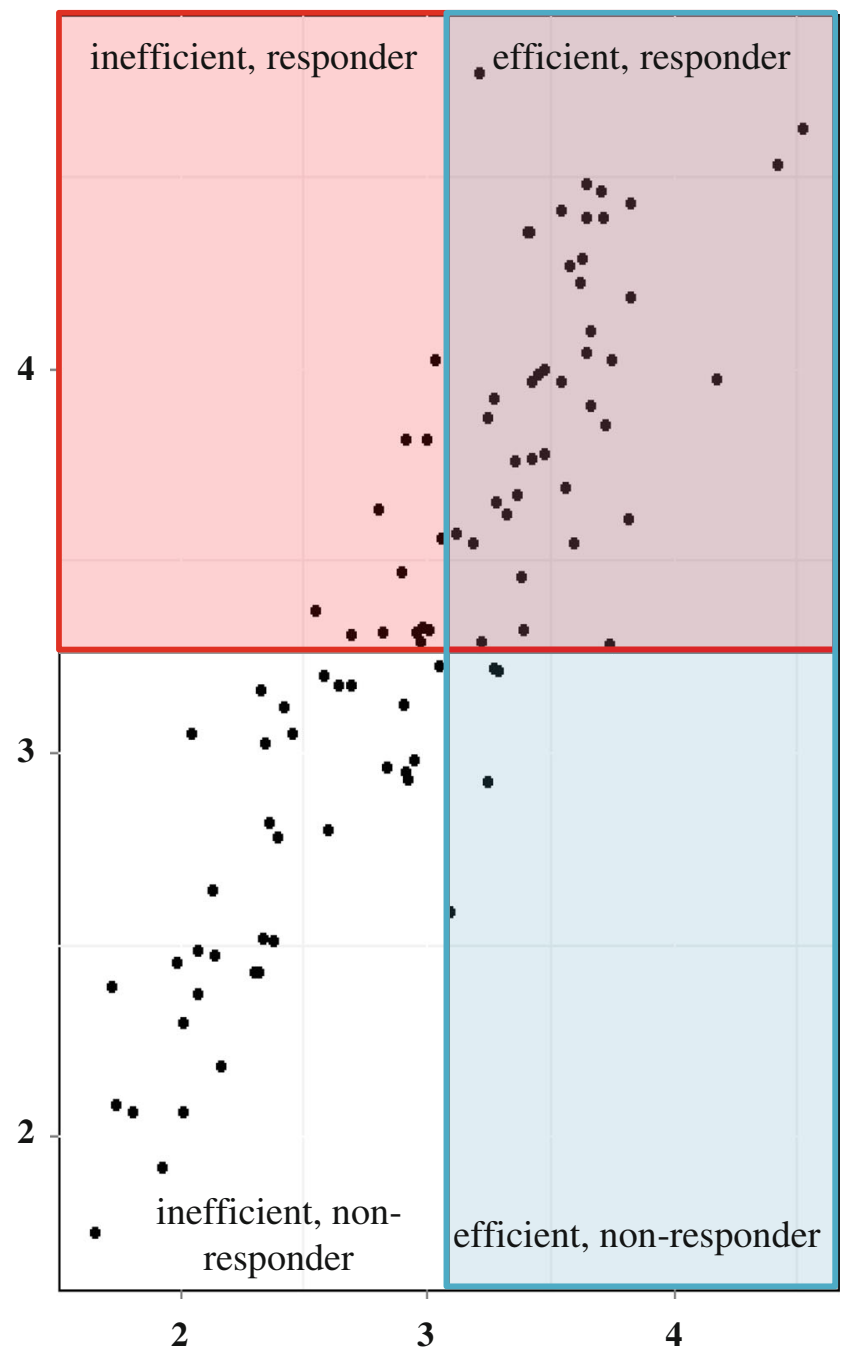

Seed yield in $\mathrm{N}$-condition ( $\mathrm{t} / \mathrm{ha}$ )

Fig. 3 Seed yields of 92 winter oilseed rape genotypes grown under two contrasting $\mathrm{N}$ nutrition regimes $(\mathrm{N}-\mathrm{vs}$. $\mathrm{N}+$ ) in western France. Data were acquired from a trial conducted under field conditions in Le Rheu (France) in the 2009-2010 growing season (for details see Bouchet et al. submitted for publication). Rectangles highlight the responding and/or efficient genotypes according to Nyikako et al. 2014 (in red and blue, respectively)

auf'm Erley et al. 2011; Kessel et al. 2012; Ulas et al. 2013; Lee et al. 2015). Combining the genetic diversity of the spring and winter gene pools by using backcrosses, for example, may be able to enrich genetic variation for NUE improvement. Moreover, introgression of subgenomic variation from B. rapa or B. oleracea, as performed by Seyis et al. (2003), and the synthesis of new-type B. napus using other oilseed Brassica species (Wang et al. 2014) may also be able to provide new variation for NUE breeding.

In summary, despite the decrease in diversity among modern cultivars, there is potential to introduce new variation into 
the rapeseed gene pool for NUE improvement. This may be achieved by combining interpopulation genetic variation, as with the combination of diversity from spring and winter cultivars, or by the creation of F1 hybrids, or by exploiting closely related gene pools to create resynthesized rapeseed lines, or through the introgression of subgenomic variation into the B. napus genome.

\section{Factors related to nitrogen absorption and remobilization show genetic diversity in rapeseed}

\subsection{Seed yield is a good indicator of nitrogen use efficiency in rapeseed}

Improving seed yield under low $\mathrm{N}$ nutrition levels is a key step toward improving NUE (Good et al. 2004), and yield estimation under different $\mathrm{N}$ regimes can be used as an indicator of global NUE (Fig. 3). In addition, the harvest index, defined as the ratio of seed weight to total plant dry matter, and the nitrogen harvest index, defined as the ratio of seed $\mathrm{N}$ to total plant $\mathrm{N}$ at harvest, can also serve as indicators of the capacity to mobilize $\mathrm{N}$ and $\mathrm{C}$ to produce seeds. However, these indicators are complex variables that can only be acquired at the end of the crop cycle. They thus incorporate all the additional processes occurring during the crop cycle, such as plant growth, abiotic stresses, and biotic pressures, which affect their usefulness for estimation of the overall NUE. A possible strategy proposed by Thurling (1991) involves dissecting complex traits into simpler variables that can be assessed throughout the crop cycle. Recent results from Miersch (2014) suggest that the use of hybrids with a semidwarf growth habit maybe an effective strategy to increase NUE in oilseed rape. That study compared 75 semidwarf hybrids and 75 normal hybrids derived from sister doublehaploid lines crossed with the same maternal tester, evaluated at two locations under two nitrogen fertilization levels. The results revealed higher nitrogen uptake efficiency, nitrogen utilization efficiency, and seed yields in the semidwarf hybrids under low $\mathrm{N}$ and similar seed yields at high $\mathrm{N}$. The lower straw yield of the semidwarf hybrids led to an improvement in the harvest index and in nitrogen utilization efficiency at both $\mathrm{N}$ levels.

\subsection{Nitrogen uptake efficiency must be improved to maintain a high preanthesis plant nitrogen pool}

Several studies have reported that nitrogen use efficiency is more strongly correlated with nitrogen uptake efficiency than with nitrogen utilization efficiency under limiting $\mathrm{N}$ fertilization in field conditions (Berry et al. 2010; Schulte auf'm Erley et al. 2011; Nyikako et al. 2014; Miersch 2014). This suggests that enhancement of rapeseed performance under low $\mathrm{N} \mathrm{nu}$ trition primarily requires improvement of nitrogen uptake efficiency. In other words, the amount of $\mathrm{N}$ effectively remobilized from the vegetative parts to the seeds during the seed filling period is conditioned by the pool of available $\mathrm{N}$ in the aerial biomass. In support of this assumption, using a set of 29 diverse winter oilseed rape accessions grown under semicontrolled conditions, we recently demonstrated an exclusive positive relationship under low $\mathrm{N}$ fertilization between the relative aboveground biomass $\mathrm{N}$ content at flowering and NUE ( $r=0.37, P=0.047)$, measured as seed yield per unit of mineral nitrogen available in the soil (Fig. $4 \mathrm{a}$; Stahl et al. 2015). Leaf $\mathrm{N}$ content of the same genotypes, measured at flowering, also exclusively showed a significant correlation with NUE $(r=0.48, P=0.008)$ at the low N level (Fig. 4b; Stahl et al. 2015).

In winter oilseed rape, nitrogen uptake efficiency needs to be investigated primarily at the beginning of the crop cycle, since a quarter to a third of the total $\mathrm{N}$ uptake occurs before winter (Cramer 1993) and most of the root system is fully developed before flowering (Barraclough 1989; Rahman and McClean 2013; Le Deunff and Malagoli 2014). Generally, the absorption of mineral ions by the plant depends primarily on their availability, which is defined by the quantity of ions present in the soil, the capacity for ion exchange between soil and solute, and the ability of the roots to take up the minerals. In the case of nitrate $\left(\mathrm{NO}_{3}{ }^{-}\right)$, the main source of mineral $\mathrm{N}$ absorbed by plants, soil retention is low and roots have a broad action perimeter spanning several centimeters. Nitrogen absorption therefore depends essentially on soil hydric reserves, the volume of soil investigated by the roots, and the capacity for $\mathrm{N}$ absorption per unit root length.

Different studies have assessed genetic variation for root mass, root length, and root/shoot ratio in commercial winter rapeseed varieties and doubled haploid lines at early stages of development and at flowering, under both field and controlled conditions (Kamh et al. 2005; Schulte auf'm Erley et al. 2007; Rahman and McClean 2013). All of these studies stressed the importance of root length over total root biomass. In our set of 30 diverse winter rapeseed accessions, we found additional evidence of variation in the response of the total root dry weight to $\mathrm{N}$ constraints at harvest (Fig. 5). As root growth and maintenance are energetically costly, root architecture is a lever to optimize the balance between nitrogen absorption ability and metabolic cost (Lynch 2014). From this perspective, increasing the root surface by increasing fine root density has been considered as one possible strategy in other crops (White et al. 2013) such as maize (Wiesler and Horst 1994), faba beans (Kage 1997), and Kentucky bluegrass (Sullivan et al. 2000).

Assessment of the root architecture of winter oilseed rape genotypes revealed considerable genetic variation for the proportion of fine roots (Fig. 6; A. Stahl and R. Snowdon, 
Fig. 4 Correlations between NUE and N content in the total aboveground biomass (a) and the leaves of rapeseed genotypes at the flowering stage (b). Data were acquired from 29 winter rapeseed genotypes grown under semicontrolled conditions under two contrasting $\mathrm{N}$ nutrition regimes (Stahl et al. 2015)

\section{a}

Above-ground biomass $\mathbf{N}$ content

at flowering $(\%)$

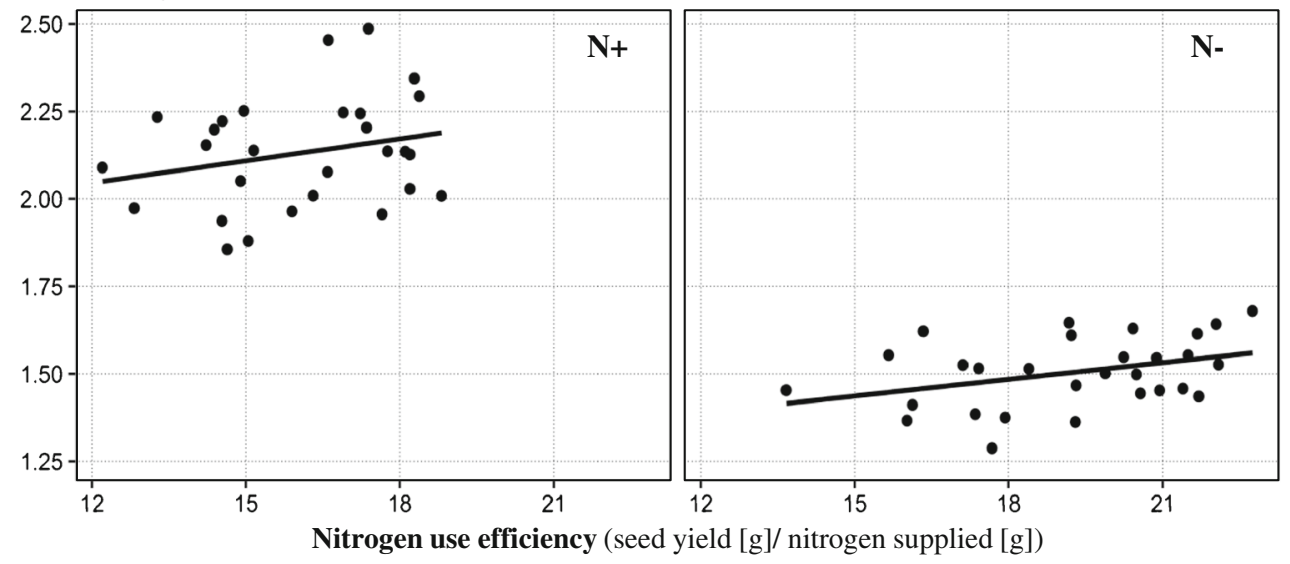

b

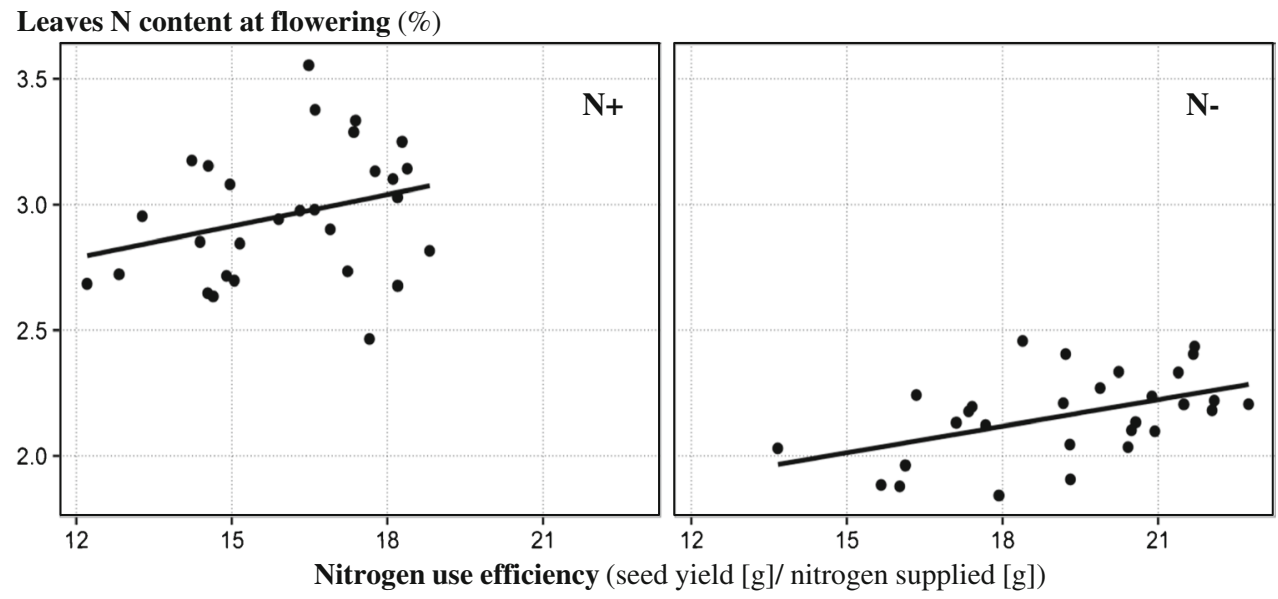

unpublished data). In addition, contrasting root exploration profiles were observed in two winter rapeseed ideotypes under field conditions (Albert et al. 2008), but the study of such traits remains difficult and needs considerable improvement.

Although Kamh et al. (2005) suggested that the nitrogen uptake efficiency of rapeseed is primarily determined by root growth rather than by the $\mathrm{N}$ uptake rate per unit of root surface, this latter trait still must not be neglected. Genetic variation in the activity of various nitrate and ammonium transporters, which move $\mathrm{N}$ across membranes, could be relevant for nitrogen uptake efficiency in rapeseed (Schulte auf'm Erley et al. 2007) and should be further studied (reviewed in Xu et al. 2012).

Although a large proportion of acquired $\mathrm{N}$ is absorbed and stored in the shoot during the vegetative stage, $\mathrm{N}$ absorbed after flowering and during the seed filling period contributes to the available plant $\mathrm{N}$ pool, maintaining the global functioning of the plant, and it may be remobilized later in the seeds. The notion that $\mathrm{N}$ uptake after flowering is negligible in rapeseed was questioned by Wiesler et al. (2001), who compared two winter oilseed rape ideotypes that follow two different models of $\mathrm{N}$ use: cultivars with better remobilization of $\mathrm{N}$ taken up before flowering, named the "improved traditional ideotype," and cultivars with a higher nitrogen uptake efficiency during the reproductive stage, the so-called "alternative ideotype." The study concluded that the "alternative ideotype" offered a greater prospect for improving the global NUE of rapeseed, because seed yield was correlated with $\mathrm{N}$ uptake during reproductive growth and with the photosynthetic activity of the leaves at the end of flowering. This was confirmed by several studies performed in the field that showed that postflowering nitrogen uptake efficiency had a significant effect on total NUE and that this period was the most important phase in discriminating varieties in terms of yield (Berry et al. 2010; Schulte auf'm Erley et al. 2011; Ulas et al. 2013). More precisely, Malagoli et al. (2005a) showed that $30 \%$ of the total plant $\mathrm{N}$ of a genotype grown in field conditions was absorbed during seed filling, even though this represented only $27 \%$ of the total seed N. However, to our knowledge, no study of rapeseed has associated nitrogen 
Fig. 5 Genetic diversity for root length (a) and dry weight (b) in 30 winter oilseed rape genotypes. The genotypes were grown in 90 $\mathrm{cm}$ deep containers, filled with $135 \mathrm{~kg}$ of a sand/soil mixture $(1: 1)$ and fertilized with the equivalent of $75 \mathrm{~kg} \mathrm{~N}^{-1}$ (yellow) and $235 \mathrm{~kg} \mathrm{~N} \mathrm{ha}^{-1}$ (green). Root data were assessed at the end of the growth cycle after harvest of the aboveground biomass. Least significant differences at the 0.05 level were $15.57 \mathrm{~cm}$ for root length and $21.25 \mathrm{~g}$ for root biomass a

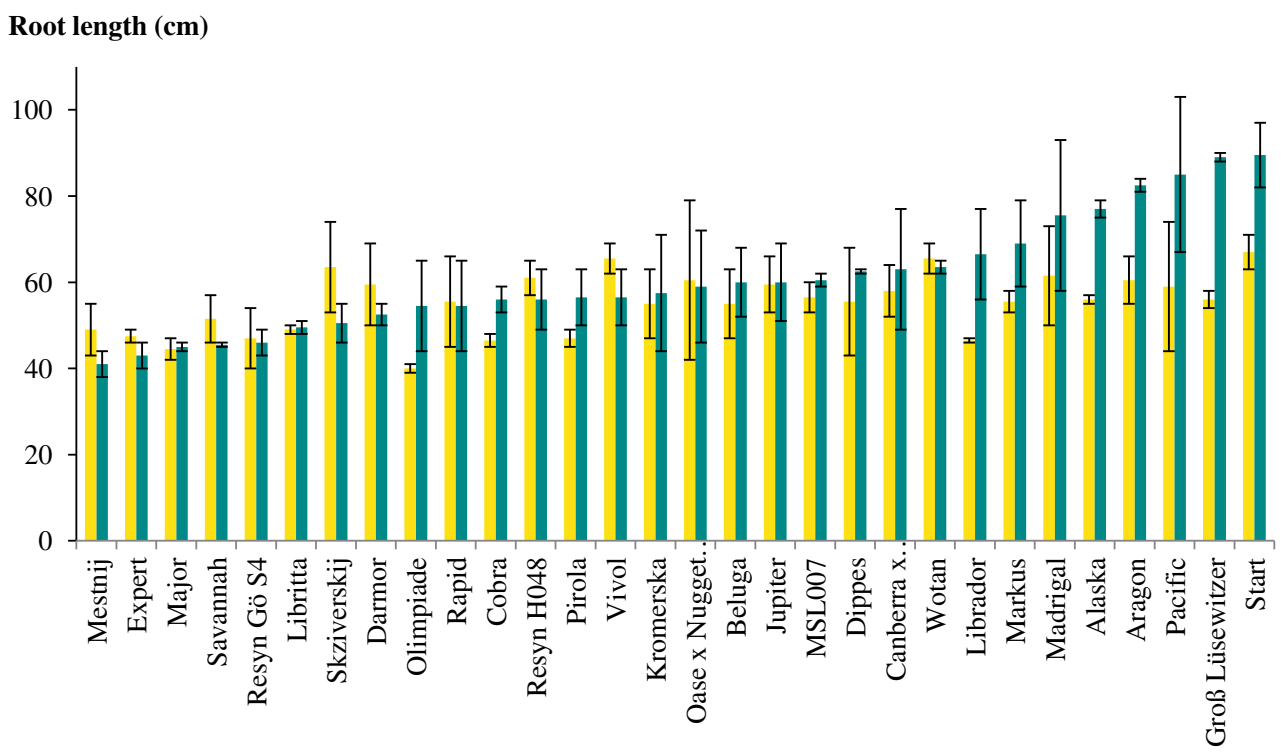

b

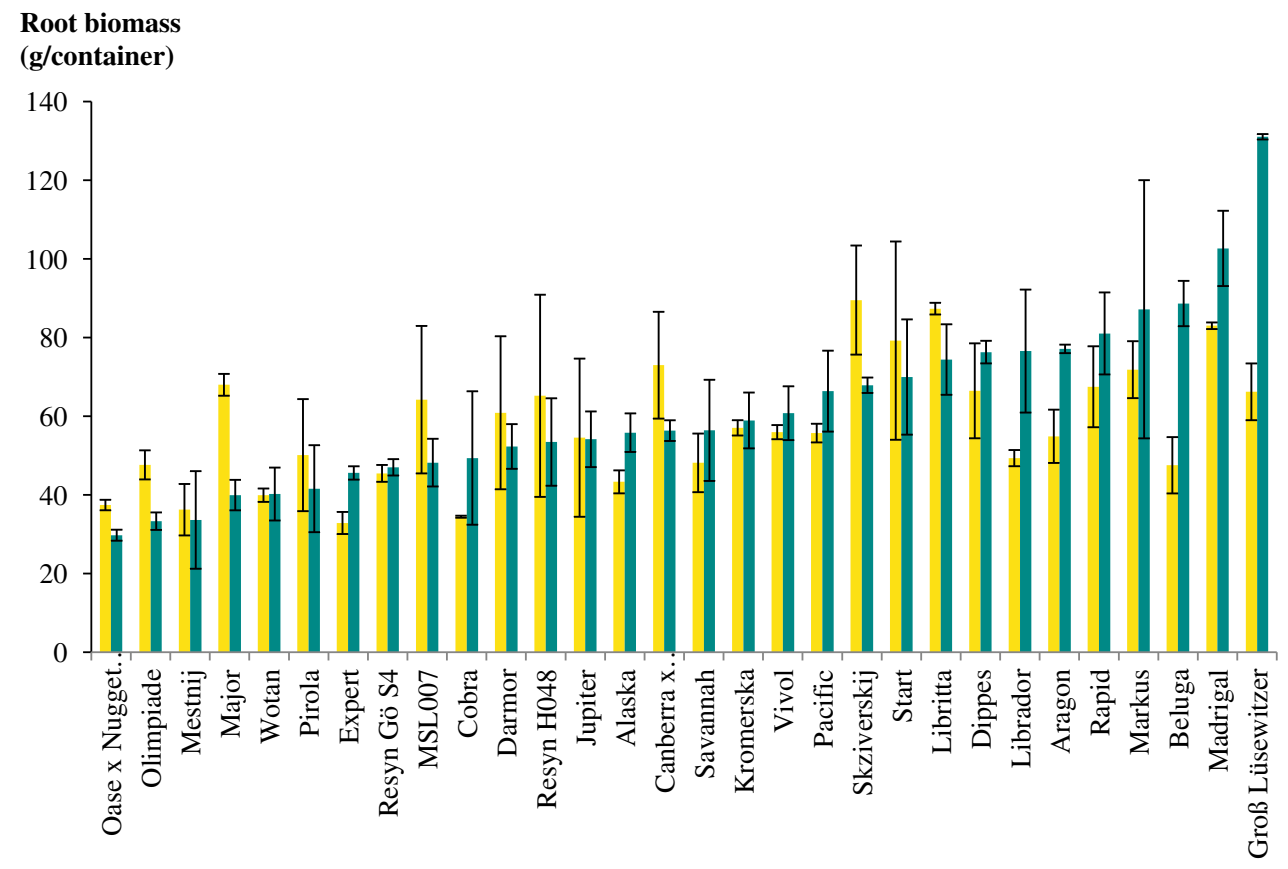

uptake efficiency with soil $\mathrm{N}$ resources at critical developmental stages, such as flowering and seed filling. This may bias the actual estimation of the efficiency of post-flowering nitrogen uptake.

\subsection{The post-anthesis nitrogen balance between source organs and sink organs needs optimization}

Flowering is a paroxysm of change from the vegetative to reproductive stage, initiated in rapeseed at the end of autumn during floral initiation (Fig. 2). This phase is characterized by a massive change in source-sink relationships. During flowering, the vegetative plant segments switch from being sink organs to source organs, with associated modifications in the $\mathrm{N}$ fluxes from older to younger tissues and to the reproductive organs (Le Deunff and Malagoli 2014). Labeling studies in Arabidopsis thaliana (Taylor et al. 2010) and B. napus (Rossato et al. 2001; Malagoli et al. 2005a) showed that the N accumulated in the seeds at harvest originates mainly from the degradation of proteins in vegetative plant segments. However, considering that different parts of the plant, such as the main raceme vs. the side branches, enter the generative 
Fig. 6 Comparison of root morphology at harvest between winter oilseed rape genotypes grown under semicontrolled conditions with low $\mathrm{N}$ input. Cultivar "Expert" showing few lateral roots (a). Cultivar "Groß Lüsewitzer" with intense lateral root network (b). Both pictures were taken on the day of seed harvest and represent the roots from nine container-grown plants grown with low $\mathrm{N}$-fertilization levels $\left(75 \mathrm{~kg} \mathrm{~N} \mathrm{ha}^{-1}\right.$ as an equivalent) (A. Stahl and R. Snowdon, unpublished data) a

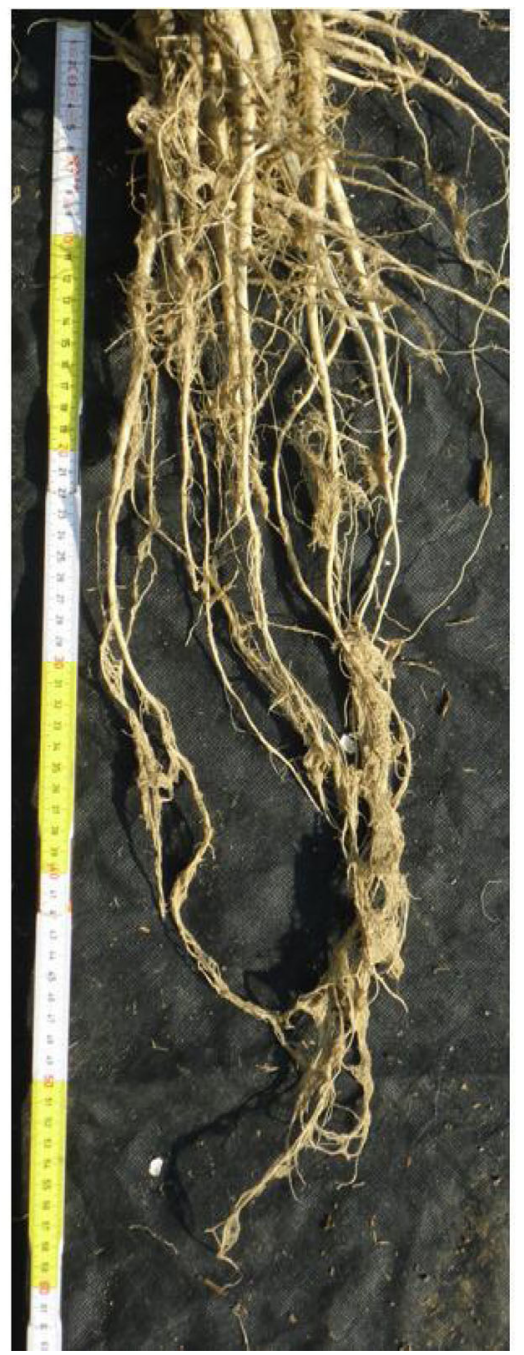

b

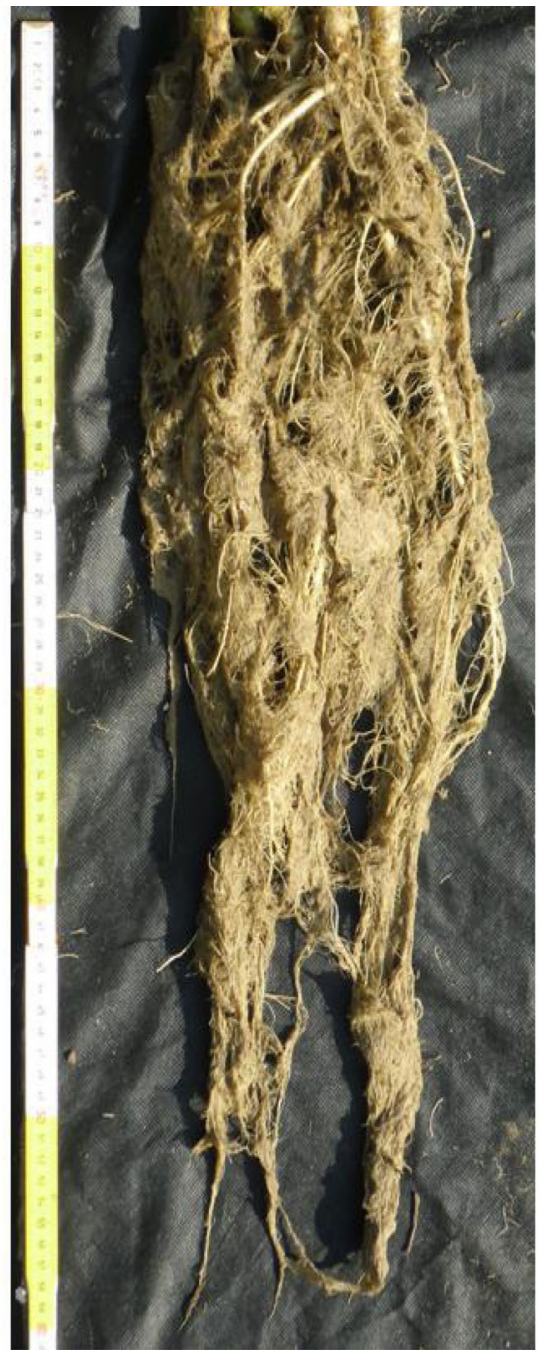

phase sequentially, multiple overlapping source-sink situations are possible in rapeseed. This asynchrony between $\mathrm{N}$ source availability in old leaves and $\mathrm{N}$ requirements in seeds, along with incomplete protein hydrolyzation in the source organs, can lead to noteworthy $\mathrm{N}$ losses from fallen leaves (Aufhammer et al. 1994; Diepenbrock 2000; Rossato et al. 2001; Malagoli et al. 2005a; Ulas et al. 2013; Avice and Etienne 2014). Leaf senescence is therefore a critical stage at the intersection of $\mathrm{N}$ uptake and $\mathrm{N}$ remobilization in the reproductive organs (Schulte auf'm Erley et al. 2007).

\subsubsection{Following the senescence process in rapeseed}

Avice and Etienne (2014) pointed out the difficulty of precisely determining the progress of the senescence process. Direct measurement of leaf chlorophyll content is commonly used to monitor leaf senescence. For instance, the SPAD meter value (Soil Plant Analysis Development) is an efficient nondestructive way to access leaf chlorophyll content by measuring the light transmittance of a sample (Wood et al. 1992). This may be why Schulte auf'm Erley et al. (2007) observed a good correlation between SPAD meter values and photosynthetic rate in rapeseed. In addition, several other biomarkers have been set up for evaluation of leaf senescence. For instance, Gombert et al. (2006) developed a molecular method based on the kinetic expression of two genes that are upregulated (SENESCENCE ASSOCIATED GENE 12; SAG12) or downregulated (CHLOROPHYLL a/b-BINDING PROTEIN; Cab) during leaf senescence. The inversion of the relative expression levels of these two genes defines the onset of leaf senescence. More recently, it was demonstrated that cellular structural changes associated with leaf senescence can be monitored by noninvasive ${ }^{1} \mathrm{H}-\mathrm{NMR}$ relaxometry (Musse et al. 2013; Sorin et al. 2015). In addition, the NMR signal captured chloroplast dismantling and was therefore judged to be a precise indicator of leaf senescence (Sorin et al. 2015); it has been tested on two genotypes showing contrasting responses to $\mathrm{N}$ depletion (Sorin et al. 2016). 
3.3.2 The "stay-green" phenotype may offer an opportunity for improvement of source-sink relationships

The "stay-green" phenotype, designating those plants with altered chlorophyll catabolism (Gregersen et al. 2013), often refers to crop species with delayed leaf senescence (Thomas and Ougham 2014). It is correlated with higher NUE in several species including A. thaliana, maize, and wheat (Spano 2003). Indeed, maintaining a high photosynthetic activity may allow the plant to carry on producing carbohydrate nutrients during the late stages of the crop cycle. Further remobilization to younger organs and seeds may eventually increase the final yield (Habekotté 1993). Examples of the relationship between the staygreen phenotype and seed yield in several species were given by Gregersen et al. (2013). However, the stay-green phenotype is not necessarily related to prolonged photosynthetic activity. Indeed, in many cases, this phenotype reflects an altered chlorophyll catabolism but with other senescence processes intact (Thomas and Howarth 2000). Hence, studies in rice and wheat reported no significant correlation, or even a negative correlation, between staygreen and seed yield (see Gregersen et al. 2013 and references therein).

Along with leaf area index and radiation use efficiency, the stay-green phenotype in rapeseed is expected to be related to the temporal span of nitrogen uptake efficiency during the reproductive stage (Diepenbrock 2000; Rathke et al. 2006), and it may be a source of genetic variation for enhancement of NUE. For instance, Schulte auf'm Erley et al. (2007) found significant genotypic differences in leaf senescence when comparing six contrasting, N-efficient winter oilseed rape accessions in nutrient solution experiments and in field conditions. In particular, positive correlations were found between delayed leaf senescence and $\mathrm{N}$ efficiency. In addition, Wiesler et al. (2001) found that the most $\mathrm{N}$-efficient cultivar in their study showed better photosynthetic capacity at the end of flowering. Grafting experiments revealed that homeostasis of biologically active cytokinins was the predominant leaf-inherent feature exhibiting genetic variation in N-limitationinduced leaf senescence (Koeslin-Findeklee et al. 2015a). However, unlike in other crop species such as cereals, pod photosynthetic activity increases after flowering in rapeseed, making the relative contribution of leaf photosynthetic activity less important (Gammelvind et al. 1996). Besides, late $\mathrm{N}$ remobilization may lead to greater $\mathrm{N}$ losses through a combination of leaf loss and a high N/C ratio in stems at harvest (Kaiser et al. 1998; Baggs et al. 2000). Hence, the superior $\mathrm{N}$ efficiency of hybrids compared to inbred lines, when studied under $\mathrm{N}$ limitation, is mainly related to nitrogen remobilization efficiency and not to delayed leaf senescence (Koeslin-Findeklee et al. 2014).

\subsubsection{Nitrogen remobilization efficiency in rapeseed}

According to Malagoli et al. (2005b), optimizing nitrogen remobilization efficiency from vegetative to reproductive tissue could improve seed yield by $15 \%$. In this case, nitrogen remobilization efficiency could be enhanced by synchronizing $\mathrm{N}$ source availability and $\mathrm{N}$ demand in the seeds. In rapeseed, the stems have been described as N-storage buffer organs that could improve this synchronization (Hocking et al. 1997; Rossato et al. 2001; Malagoli et al. 2005a). According to Girondé et al. (2015), a high amount of $\mathrm{N}$ in the stems at the beginning of the reproductive stage, and better $\mathrm{N}$ remobilization from the stems to the seeds, are characteristic features of high nitrogen remobilization efficiency. There is evidence for genetic variation in $\mathrm{N}$ stem remobilization in rapeseed (Berry et al. 2010; Girondé et al. 2015), but that variation is not always correlated with nitrogen utilization efficiency under low $\mathrm{N}$ supply. This finding was confirmed by data from diverse winter rapeseed accessions grown under low and high $\mathrm{N}$ fertilization, where the $\mathrm{N}$ content in the stems at flowering was not significantly related to nitrogen utilization efficiency (Fig. 7). In contrast, the $\mathrm{N}$ content in stems after seed harvest was negatively correlated with NUtE under both $\mathrm{N}$ conditions. At high $\mathrm{N}$ fertilization levels, the Pearson coefficient of correlation $(r=-0.681, P<0.001)$ was much stronger than at low $\mathrm{N}$ fertilization levels $(r=-0.399, P=0.036)$. Moreover, it was shown that while the $\mathrm{N}$ content in stems varied at flowering between the fertilization levels, it was similar at maturity (Stahl et al. 2015).

Tilsner et al. (2005) showed that the phloem loading of amino acids was not limiting for nitrogen remobilization efficiency, and they hypothesized that sink capacity rather than source strength was the main bottleneck for $\mathrm{N}$ remobilization in rapeseed. The final sink capacity of rapeseed can be enhanced primarily through the improvement of the yield components per se. This was corroborated by several studies showing significant correlations between harvest index and nitrogen utilization efficiency (Berry et al. 2010; Schulte auf'm Erley et al. 2011; Nyikako et al. 2014; Stahl et al. 2015), demonstrating that increasing the sink capacity for $\mathrm{N}$ and $\mathrm{C}$ would increase the harvest index. Increasing the total amount of protein in the seeds may be another way to enhance the sink strength and the final nitrogen utilization efficiency of rapeseed. Several studies have shown that genotypes with high nitrogen utilization efficiency values are characterized by low relative seed protein content (Schulte auf'm Erley et al. 2011; Koeslin-Findeklee et al. 2014). Schulte auf'm Erley et al. (2011) showed that genotypes with lower seed N content accumulated more seed dry matter for a given amount of $\mathrm{N}$ accumulated, possibly because of a higher photosynthetic rate in the pods or a higher efficiency of oil production.

At the molecular scale, an accumulation of the protease inhibitor BnD22 was observed in younger leaves in a low $\mathrm{N}$ 
Fig. 7 Correlation between nitrogen utilization efficiency and $\mathrm{N}$ content in the stems at flowering (green) and maturity (yellow), measured on 28 WOSR accessions at high (left) and low (right) $\mathrm{N}$ fertilization (data from Stahl et al. 2015). Gray shaded area depicts $95 \%$ confidence interval

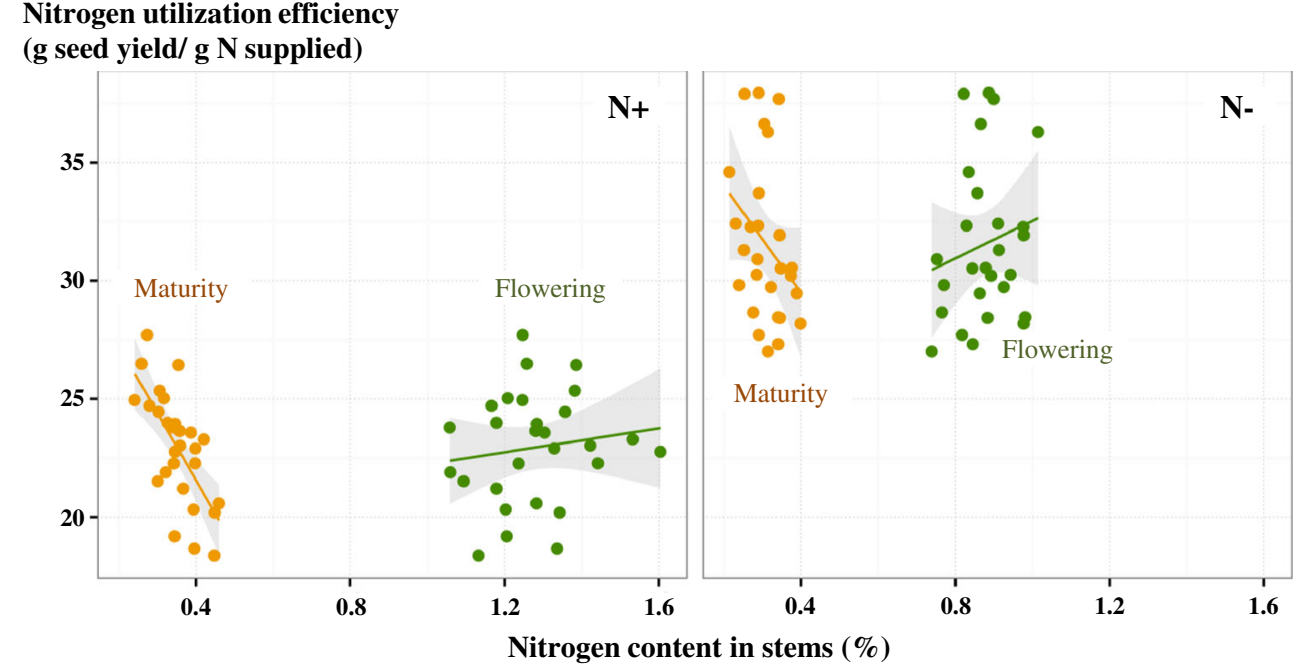

context. BnD22 acts as a protector of chlorophyll when combined with other water-soluble chlorophyll-binding proteins (WSCPs), significantly delaying leaf senescence and ensuring maintenance of leaf sink strength (Etienne et al. 2007).

\subsection{Defining the ideotype of a nitrogen-efficient rapeseed}

Both $\mathrm{N}$ absorption and $\mathrm{N}$ utilization must be considered in attempts to improve the global NUE in rapeseed (Ulas et al. 2013). These two factors can be deconvoluted into subtraits which, when studied in detail, show a wide range of individual genetic variability.

Canopy architecture, involving interactions among the organs of a single plant as well as interactions among plants, must also be considered in developing efficient NUE breeding programs. For instance, at the end of flowering, leaf insertion and plant density may impact the total leaf area index and the photosynthetic activity of the lower leaves (Malagoli et al. 2005a). Habekotté et al. (1997) recommended combining traits such as high leaf area index, apetalous flowers, and erect pods to maximize radiation interception and yield potential. However, direct comparison of an apetalous hybrid line and the corresponding petaled near-isogenic line revealed that seed yield was not significantly higher in apetalous plants, except when the plants were affected by Sclerotinia sclerotiorum (Zhao and Wang 2004).

As shown previously, the sink-source relationship seems to be the key factor underlying $\mathrm{N}$ remobilization in rapeseed, given the species' indeterminate growth habit. The timing of each developmental phase therefore contributes significantly to the final $\mathrm{N}$ efficiency of the plants. Flowering defines the culmination of the switch of leaf function from $\mathrm{N}$ sink to $\mathrm{N}$ source, initiated at the end of winter, and it conditions the efficiency of $\mathrm{N}$ remobilization from vegetative to reproductive organs. According to Malagoli et al. 2005a, an ideal genotype would exhibit early flowering in order to synchronize $\mathrm{N}$ mobilization with the $\mathrm{N}$ demand of the maturing pods. Especially at low $\mathrm{N}$ supply, this hypothesis was supported by Stahl et al. (2015). On the other hand, early flowering may limit the vegetative growth of the plant and the amount of $\mathrm{N}$ accumulated before flowering, which could lead to a reduced $\mathrm{N}$ pool for subsequent remobilization. Unfortunately, due to these and other pleiotropic effects associated with the modification of flowering behavior, optimizing this physiological tradeoff between $\mathrm{N}$ uptake and remobilization capacity can be a complicated procedure for breeders.

Accounting for interactions between nitrogen and carbon metabolism is essential when considering NUE. In rapeseed, this interaction is particularly relevant in relation to the negative correlation between oil and protein content of the seeds (Bouchet et al. 2014; Stahl et al. 2015). Because the main breeding objective is oil yield, both of these traits have to be considered in breeding programs because the protein component represents the major $\mathrm{N}$ sink. Indeed, an N-efficient genotype may result in a lower oil/protein ratio, especially under high $\mathrm{N}$ conditions, which may not be in line with present breeding goals. With this in mind, Masclaux-Daubresse et al. (2010) suggested that breeding for delayed senescence could lead not only to higher yields but also to a decrease in nitrogen remobilization efficiency and protein content.

The study of Fei et al. (2013) indicated an inverse relationship between seed oil content potential on the one hand, and biomass, $\mathrm{C}$, and $\mathrm{N}$ accumulation on the other. Hence, the partition of mobilized $\mathrm{C}$ and $\mathrm{N}$ from vegetative biomass to seeds seems to determine the realized seed oil content much more. Selection for this aspect would allow lower $\mathrm{N}$ fertilizer inputs and still produce high oil yields. From an agroeconomical perspective, it is also worth considering the high value of rapeseed protein, in light of its added benefit as an $\mathrm{N}$ sink, for improved resource efficiency. 
4 Advances in breeding for nitrogen-efficient rapeseed with optimized oil yield

\subsection{Breeding strategies must be oriented to genotype-by-environment interactions}

Defining the environments where selection is performed (selection environments) and the environments where the future variety will be grown (target environments) are key issues driving breeding strategies. On the one hand, the objective of a breeding program may be the creation of varieties adapted to specific environments. In the case of so-called direct selection, the selection environment should be very similar to the target environment. On the other hand, in the case of indirect selection, the creation of varieties adapted to a broad range of target environments requires a range or a set of diverging selection environments. In the latter situation, the question arises whether the selection of a trait in one environment can be transposed to another. Genotype $\times$ environment $(G \times E)$ interactions are therefore crucial in plant breeding and have been extensively studied in many crops.

In the case of NUE, the breeding strategy depends upon the stress level of the target environment and the loss of yield between the selection and target environments. In maize, Bänziger et al. (1997) found that direct selection was preferable when grain yield loss between the selection and target environments exceeded $43 \%$. A moderately $\mathrm{N}$-stressed target environment, with a high genetic correlation between the selection and target environments, may therefore allow for indirect selection (Cormier et al. 2013). In rapeseed, studies reporting interactions between genotypes and the $\mathrm{N}$ nutrition regime $(\mathrm{G} \times \mathrm{N})$ remain scarce. Miro (2010) found significant quantitative trait locus (QTL) $\times \mathrm{N}$ interactions for most yieldrelated and NUE-related traits, whereas Gül et al. (2002) and Bouchet et al. (2014) found relatively consistent control of yield by QTLs between different $\mathrm{N}$ nutrition conditions. In addition, the QTL values detected in Miro (2010) and Bouchet et al. (2014) varied between the different trials, demonstrating a strong effect of other environmental factors on $\mathrm{N}$ efficiency loci. In fact, direct selection appears to be a convenient strategy for NUE breeding in rapeseed (Kessel et al. 2012), an observation that has also been reported for wheat (Brancourt-Hulmel et al. 2005).

Evaluating $\mathrm{G} \times \mathrm{N}$ interactions by characterizing plant $\mathrm{N}$ stress in each study environment is a prerequisite for determining the best breeding strategy for NUE-related traits. In forage grass, Lemaire et al. (1984) assessed the negative relationship between crop biomass and the minimum $\mathrm{N}$ concentration necessary to produce the maximum aboveground biomass (the critical $\mathrm{N}$ concentration). With this equation, a theoretical critical dilution curve could be established, corresponding to the ideal nitrogen nutrition status for a range of aerial biomass values. The ratio between the observed $\mathrm{N}$ concentration of a plant sample and the critical $\mathrm{N}$ concentration at a given aerial biomass, called the nitrogen nutrition index (NNI), provides information on the $\mathrm{N}$ status of the studied sample. This index is commonly used in major crop NUE studies. Colnenne et al. (1998) established a nitrogen dilution curve for rapeseed. Although based only on a single wintertype variety (Goeland) grown in different pedo-climatic regions of France, this curve remains the standard for evaluating $\mathrm{N}$ nutrition status in rapeseed. We found a strong significant correlation between the NNI and the average seed yield of a winter oilseed rape diversity set grown in five environments (Fig. 8).

\subsection{Identification and characterization of nitrogen efficiency loci in rapeseed}

\subsubsection{Genetic control of traits related to seed yield}

The genetic control of yield-related traits has been extensively studied in rapeseed using statistical tools such as linkage mapping and linkage disequilibrium analyses (genome-wide association studies; GWAS), resulting in the identification of thousands of QTLs associated with yield in different genetic backgrounds and environments. The integration of those data into meta-analyses may allow the identification of important genomic regions that are potentially usable in breeding programs. For example, Zhou et al. (2014) integrated information from 1960 QTLs for seed yield traits that were detected in 15 independent studies, identifying 142 loci that were conserved between the different analyses, including 25 multifunctional loci. Such information represents a first step toward the identification of candidate genes, although fine mapping is complicated in rapeseed by the highly complex genome, the long generation time, and the low recombination rates. Some genetic analyses have investigated the genetic control of yieldrelated traits under N stress per se (Gül 2002; Miro 2010; Bouchet et al. 2014), but to date, we are aware of no studies that describe the B. napus genome regions associated with NUE-related traits.

\subsubsection{Genetic control of traits related to nitrogen uptake efficiency}

Several studies have addressed the genetic control of root system vigor in $B$. napus in the context of adaptation to various environmental conditions (Rahman and McClean 2013), especially drought stress (Fletcher et al. 2014) and phosphorous stress (Yang et al. 2010; Shi et al. 2012). No potential pleiotropic relationships were found between flowering time and root vigor, root biomass, and root length, suggesting common genetic control (Rahman and McClean 2013; Fletcher et al. 2014). In reciprocal crosses between spring-type and winter-type B. napus, Rahman and McClean (2013) 
Fig. 8 Correlation between nitrogen nutrition index (NNI) values and overall seed yield of 92 winter oilseed rape genotypes grown under two contrasting $\mathrm{N}$ nutrition regimes $(\mathrm{N}-\mathrm{vs} . \mathrm{N}+)$ at five different sites in western France. The NNI values were measured on controls at the beginning of spring elongation for both $\mathrm{N}$ conditions. The Pearson correlation coefficients $(r)$ for the $\mathrm{N}-$ and $\mathrm{N}+$ conditions were 0.96 and 0.97 , respectively
Seed yield ( $\mathrm{t} / \mathrm{ha})$

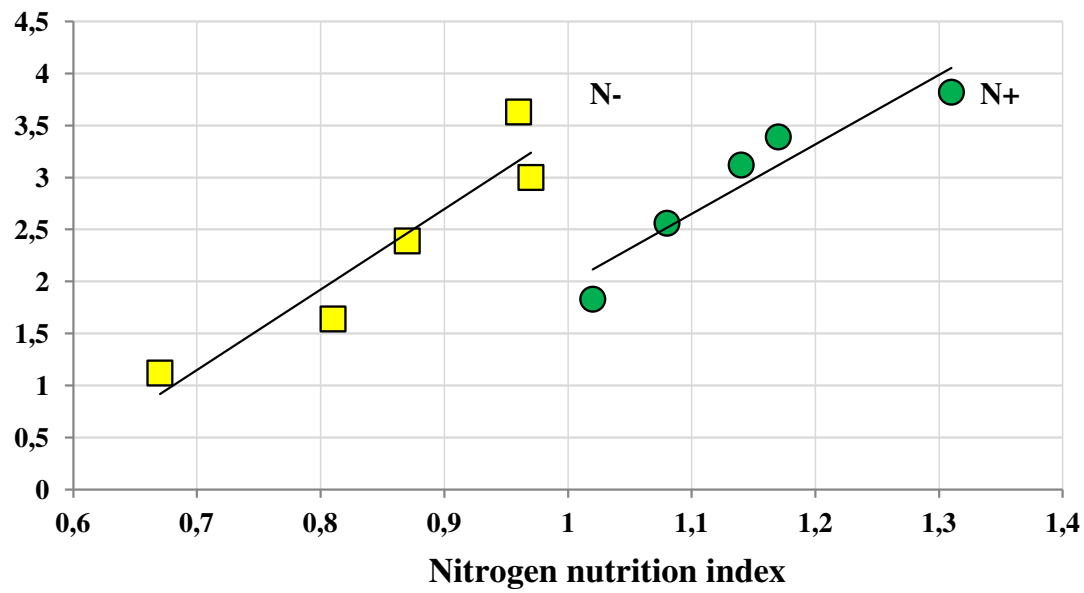

hypothesized a trigenic dominant control of root vigor, based on the segregation ratio of F2 populations. Using linkage analysis on a population of recombinant inbred lines and a doubled haploid population, Yang et al. (2010) and Shi et al. (2012) detected QTL clusters for root length, lateral root number, root surface area, root biomass, and root volume that were specific to low-phosphorous treatments. Such studies provide the first insight into potentially interesting variation and its underlying genetic control, although care must be taken not to overestimate the importance of major QTLs in mapping populations from strongly differentiated parents, since such QTLs are often dependent on the specific genetic background, particularly in crosses between spring and winter forms.

Although they have been extensively studied in A. thaliana, little information is available on the genes responsible for variation in root-related traits and their regulation in response to $\mathrm{N}$ availability in rapeseed. In A. thaliana, root growth response to the availability of nitrate involves two distinct pathways (Zhang and Forde 1998; Zhang and Forde 2000): a direct effect of external nitrate on the MADS-box transcription factor ARABIDOPSIS NITRATE-REGULATED 1 (Zhang and Forde 1998) and a systemic inhibitory effect by a basic leucine zipper and an LIM transcription factor (Tranbarger et al. 2003). More recently, the N-responsive CLAVATA3/ESR (CLE) peptides and the CLAVATA1 (CLVI) leucine-rich repeat receptor-like kinase signaling module were identified as playing a crucial role in the development of the lateral root system in $\mathrm{N}$-poor environments (Araya et al. 2013). Additionally, the nitrate transporters NRT1.1 (Remans et al. 2006a; Krouk et al. 2010) and NRT2.1 (Little et al. 2005; Remans et al. 2006b) are known to be crucial in nitrate sensing, independent of their uptake function (Malamy and Ryan 2001; Miller et al. 2007). Our studies indicate that different winter rapeseed varieties show different reactions to low and high nitrogen concentrations (Fig. 5). The cultivar "Groß Lüsewitzer," for example, exhibited different seed yields under low and high nitrogen fertilization (19.78 vs. $28.70 \mathrm{~g} /$ container), while no such significant difference was observed in the "Major" cultivar (22.07 vs. $22.35 \mathrm{~g} /$ container). To our knowledge, however, no study so far has elucidated the detailed genetic control of root growth and nutrient responses in B. napus. New methods for automated phenotyping of root responses under controlled conditions (Hatzig et al. 2015), in combination with high-resolution genome-wide association studies (Voss-Fels and Snowdon 2015), may help in identifying interesting variants for breeding.

\subsubsection{Genetic control of traits related to nitrogen utilization efficiency}

As in many other crops, the activity of several enzymes has been associated with $\mathrm{N}$ metabolism in rapeseed. For example, Yea et al. (2010) found higher glutamine synthetase and nitrate reductase activity in $\mathrm{N}$-efficient genotypes under $\mathrm{N}$ stress conditions. This was supported by Miro et al. (2010), who found $B$. napus nitrate transporters, and other genes implicated in nitrate regulation, underlying N-responsive QTLs. Orsel et al. (2014) found 16 BnaGLN1 genes coding for cytosolic glutamine synthase in rapeseed. In addition, two homoeologous genes (BnSAG12-1 and BnSAG12-2) coding for SAG12, a cysteine protease implicated in $\mathrm{N}$ remobilization, were observed to reach maximum expression levels at early stages of senescence (Noh and Amasino 1999). Another group of enhanced senescing genes is the $L E A F$ SENESCENCE CLONE (LSC) gene family coding for glutamine synthase, cysteine protease, or metallothione. In contrast, $C a b$ gene expression was found to decrease during senescence (Noh and Amasino 1999). A recent study identified genes showing differential expression under high and low $\mathrm{N}$ conditions in rapeseed, revealing that genes related to photosynthesis, photorespiration, and cell-wall structure are repressed under $\mathrm{N}$ starvation, whereas genes related to 
mitochondrial electron transport and flavonoid synthesis show enhanced expression (Koeslin-Findeklee et al. 2015b). The previously mentioned superiority of semidwarf hybrids with regard to nitrogen utilization efficiency was associated with two QTLs, on chromosomes A07 and A06, the latter of which is assumed to coincide with the B. napus dwarf mutation bzh (Miersch 2014).

The polyploid nature of B. napus implies the duplication of genes involved in NUE traits within the genome and their organization into large multigene families, with possible variations in spatiotemporal gene expression patterns. For instance, the 16 BnaGLN1 genes detected by Orsel et al. (2014) were organized into five distinct families that were differentially modulated according to $\mathrm{N}$ availability. Two gene families were upregulated under low $\mathrm{N}$ conditions and during leaf senescence, while one family was upregulated under high $\mathrm{N}$ conditions. Another family was not affected by the $\mathrm{N}$ nutrition level but showed higher expression in stems than in leaves. Faes et al. (2015) also demonstrated the differential expression of two subgroups of genes in the proline dehydrogenase gene family in rapeseed. These genes, ProDH1 and ProDH2, control proline catabolism, which is suspected to play a role in the remobilization of $\mathrm{N}$ from old to young leaves. While the ProDH1 genes were the most expressed subgroup at the plant level, and particularly in pollen and roots, the $\mathrm{ProDH} 2$ genes were characteristically expressed in the vascular tissues of senescing leaves.

\section{Future directions for genetic improvement of nitrogen use efficiency}

\subsection{Taking advantage of heterosis}

Hybrid cultivars are generally believed to be more N-efficient, especially under unfavorable conditions (Karamanos et al. 2005; Karamanos et al. 2006; Gehringer et al. 2007; Kessel et al. 2012). Koeslin-Findeklee et al. (2014) compared the NUE of 11 inbred lines and seven hybrids over 2 years in field experiments and demonstrated the superiority of hybrids for both nitrogen uptake efficiency and nitrogen utilization efficiency, resulting in higher overall $\mathrm{N}$ efficiency.

In classical hybrid crops like maize or sunflower, strongly differentiated heterotic pools have been developed to systematically exploit heterosis in hybrid breeding. In rapeseed, the development of distinct genetic pools is difficult due to the comparatively narrow diversity in the elite cultivars and the history of inbred-line development (Snowdon et al. 2015). Introgression between the comparatively diverse genetic pools of winter, semiwinter, and spring forms, however, may make it possible to exploit heterosis. For instance, Qian et al. (2007) showed high heterosis for seed yield in hybrids between Chinese semiwinter pollinators and spring-type mother lines from Europe and Canada. Improvement of spring-type $B$. napus through the introgression of winter-type variability was also assessed by Kebede et al. (2010), who demonstrated the heterosis effect of spring $\times$ winter doubled haploid lines over their parental lines. To avoid incompatibilities in developmental timing between these potential heterotic groups, Qian et al. (2007) suggested that the genetic material should first be adapted to the local environment before being hybridized. It should be noted that the genetic distance between heterotic groups, commonly used to determine the hybridization scheme, is often not correlated with the hybrids' performance.

Replacing subgenomes in new-type B. napus varieties by introgression from related Brassica species (Udall et al. 2004; Qian et al. 2007) represents another possibility for widening the global genetic diversity of $B$. napus by creating new allelic combinations and new intersubgenomic heterosis effects. For instance, NUE diversity of new-type $B$. napus doubled haploid lines resulting from interspecific crosses between spring B. napus lines, B. rapa, and B. carinata, along with traditional lines of $B$. napus, were tested under two $\mathrm{N}$ regimes by Wang et al. (2014). The most $\mathrm{N}$-efficient new-type B. napus doubled haploid line showed higher relative seed yield than that of the most $\mathrm{N}$-efficient traditional line, suggesting that the introgression of exotic genome components conferred better responsiveness to $\mathrm{N}$ regime change on the new-type $B$. napus doubled haploid lines. This effect may indicate intersubgenomic heterosis for NUE. However, crossing between distant heterotic groups or exotic germplasm sources may also introduce undesirable traits, and these must be eliminated to ensure the success of the breeding program. Systematic construction of heterotic groups or hybrid breeding programs with a specific focus on $\mathrm{N}$ availability nevertheless has promise for creating combinations of complementary alleles with favorable NUE traits.

\subsection{Predicting rapeseed genotypic values}

Predicting the performance of nonphenotyped individuals based on genotypic values is of considerable interest, as it may save time for genotype evaluation, reduce the costs of field selection, improve the range of available genotypes, and ultimately raise the efficiency of breeding programs.

In rapeseed, Würschum et al. (2013) evaluated the potential of genomic selection for complex traits. Even with a small number of simple sequence repeats markers, a number of genomic regions with small effects were detected that had not been found with previous QTL-mapping approaches. As highdensity genotypic information becomes more readily available for rapeseed (Edwards et al. 2013; Snowdon et al. 2015), prediction accuracy for complex traits will undoubtedly be further improved. In a first test of high-density genome-wide single nucleotide polymorphism (SNP) markers for genomic 
prediction in spring rapeseed, Jan et al. (2016) reported accurate prediction of general combining ability for seed yield and other traits in the pollinators used to generate large populations of test hybrids.

In contrast to marker-assisted selection, which is generally only successful for major genes or QTLs with large effects, genomic prediction is an appropriate method for preselection of breeding materials that have promising variation for complex traits like NUE. However, the question of the number of individuals to be tested for the prediction models remains crucial, especially if one wants to test them under multiple $\mathrm{N}$ conditions. Moreover, the development of genomic selection for NUE breeding programs may be markedly hindered by the effects of heterosis and $\mathrm{G} \times \mathrm{E}$ interactions, as shown previously, which remain challenging to integrate into the genomic selection models.

Recently, Snowdon et al. (2015) introduced the concept of heterotic haplotype capture, in which associations are sought between predicted heterozygous haplotype blocks in hybrids from large nested association mapping populations. These populations carry wide genetic diversity from exotic and synthetic founder lines, and their heterotic performance when crossed to maternal testers can be accurately predicted using genome-wide SNP data. The integration of previous information regarding NUE-related QTLs, functional genomic characterization of interesting heterotic haplotypes, and continually growing genome data based on the newly released $B$. napus genome sequence (Chalhoub et al. 2014) provides completely new opportunities to investigate the genetic basis of heterosis for NUE and yield. Given the high cost and effort involved in phenotypic screening of large breeding populations for NUE, prediction models for heterosis and yield performance are likely to play a major role in future NUE breeding programs.

\subsection{Phenotyping for nitrogen use efficiency}

The main prerequisites for correct evaluation of performance under low $\mathrm{N}$ nutrition are precise and high-quality phenotyping, along with correct estimates of plant $\mathrm{N}$ stress in different environments. So far, few tools are available for $\mathrm{N}$ stress evaluation at the canopy level. The nitrogen nutrition index calculation presented above has been used to create a tool that is now commonly used by French farmers (Parnaudeau et al. 2009). However, this method was developed on a single cultivar, in the context of French soil and climatic conditions, and so may not be transferable to other European regions or to other cultivars. Moreover, it is still difficult to routinely measure nitrogen nutrition index in diverse populations. Alternative, nondestructive methods for the estimation of plant $\mathrm{N}$ status, based on transmittance or fluorescence parameters, are reviewed by Muñoz-Huerta et al. (2013).

Improvement of NUE traits in rapeseed involves comprehensive phenotyping procedures that are difficult to set up for large numbers of genotypes and environments. Increasing data storage and computing capacities have enabled the development of new high-throughput phenotyping tools, including automated phenotyping systems for both controlled environment and field experiments.

Nondestructive aerial biomass phenotyping tools, developed in the last decade based on color or spectroscopic imaging, have already been adapted to concrete applications in plant breeding (Fiorani and Schurr 2013). For instance, a QTL analysis based on features acquired from 3D reconstructions of the plant canopy and red-green-blue imaging was performed on pepper in 2012 (van der Heijden et al. 2012). At the field scale, drones carrying onboard sensors allow dynamic acquisition of massive datasets throughout the crop cycle, including, for example, estimates of total plant biomass and leaf area index. By analyzing canopy structures under semicontrolled conditions, under contrasting $\mathrm{N}$ conditions in experiments that simulate field environments, we were able to estimate the NUE of rapeseed at the canopy level (Hohmann et al. 2016; Bissuel-Belaygue et al. 2015). This allowed for the acquisition of information from sowing to harvest at the plant level, while also taking into account $\mathrm{G} \times \mathrm{E}$ interaction effects. Root phenotyping is more difficult to develop (Postma et al. 2014).

Rhizotrons with cameras, cultivation on transparent matrices, and X-ray or magnetic resonance imaging methods are emerging approaches for exploring roots traits in $2 \mathrm{D}$ or $3 \mathrm{D}$, but such techniques remain costly and are complicated to calibrate. To accelerate breeding programs, efficient methods and platforms to screen large breeding populations for meaningful variation at early stages of development would be immensely valuable. Thomas et al. (2016) compared a "pouch and wick" high-throughput phenotyping technique to evaluate root traits such as primary root length and lateral root density of 32 elite rapeseed cultivars, along with their root vigor and seed yield, in six field experiments. They concluded that primary root length was the best predictor of early vigor and final seed yield, and that measuring lateral root density could be an additional lever for the improvement of nutrient uptake in rapeseed. This technique was not evaluated under nutrient depletion, however. Balint and Rengel (2008b) showed that there was little consistency in the N-efficiency rankings of 12 rapeseed varieties between the vegetative and the reproductive stages, suggesting that a finer evaluation of key traits across several developmental stages should be conducted. Phenotypes have to be evaluated throughout the vegetation period until seed harvest (Fig. 2) to prevent the superiority of one trait being masked by the disadvantageous effects of another trait. A possible strategy for screening large collections is to use genomic selection to prescreen for potential genome-wide variation associated with nitrogen uptake efficiency, nitrogen utilization efficiency, and root traits (Cormier et al. 2013). Preselection of candidates with high 
predicted NUE values can potentially reduce the number of breeding materials that need to be phenotyped in complex assays or field trials, thereby improving prospects for accurate selection at the top level of available NUE variation.

\section{Conclusion}

Research on NUE in rapeseed is still a priority in Europe and abroad. Large research projects investigating and generating genetic diversity for NUE in rapeseed have been recently completed or are currently in progress, in France (RAPSODYN: www.rapsodyn.fr), in Germany (PreBreedYield: Samans et al. 2013), and in the UK (NUECrops: http://research.ncl.ac.uk/nefg/nuecrops/). Good et al. (2007) demonstrated the promise of alternative breeding technologies in generating new diversity by improving the NUE of rapeseed through the overexpression of a barley alanine aminotransferase gene in the roots. $\mathrm{N}$ efficiency is also now gaining importance in the marketing of new rapeseed varieties. In 2014, for example, a new rapeseed hybrid ("DKException") was promoted for its improved $\mathrm{N}$ efficiency, reflecting a growing interest in NUE from a commercial point of view. This commercial interest will encourage further scientific and technical investigations of NUE mechanisms in rapeseed, in order to ensure the economic and environmental sustainability of this important crop in the future.

Acknowledgments The authors thank Markus Kolmer, Maximilian Henning, Lothar Behle-Schalk, and Salman Arif from Justus Liebig University for excellent technical support during plant experiments and root phenotyping. We also thank Benjamin Wittkop and Wolfgang Friedt for useful comments on the study. The members of the Brassica group from INRA Le Rheu (France) are acknowledged for support and discussions, especially Alain Bouchereau, Françoise Le Cahérec, MarieFrançoise Niogret, Laurent Leport, and Carole Deleu. This review was prepared within the framework of projects funded by the French National Research Agency (ANR; grants to NN for GENERGY and FACCE-ERANET + SYBRACLIM), the French program "Investments for the Future" (grant to NN for RAPSODYN), the German Ministry of Education and Research (BMBF; grants to RS for PreBreedYield and FACCE-ERA$N E T+S Y B R A C L I M)$, and the German ministry of Nutrition and Agriculture, Agency for Renewable Resources (BMEL/FNR; grant to RS for NUE in Rapeseed). ASB is the recipient of a 3-year PhD fellowship from the French Ministry of Education and Research.

\section{References}

Albert B, Laperche A, Orsel M, Bregeon M, Busnot S, Bissuel C (2008) Architecture racinaire et efficience d'utilisation de l'azote chez deux génotypes de colza cultivés en conditions contrastées d'alimentation azotée XI journées du réseau "Biotechnologies végétales/ Amélioration des plantes et sécurité alimentaire-Biotech 2008", Agrocampus Rennes, France.

Araya T, Miyamoto M, Wibowo J, Suzuki A, Kojima S, Tsuchiya YN, Sawa S, Fukuda H, Wirén NV, Takahashi H (2013) CLE-
CLAVATA1 peptide-receptor signaling module regulates the expansion of plant root systems in a nitrogen-dependent manner. Proc Natl Acad Sci U S A 111(5):2029-2034. doi:10.1073/pnas.1319953111

Aufhammer W, Kübler E, Bury M (1994) Nitrogen uptake and nitrogen residuals of winter oilseed rape and fallout rape. J Agron Crop Sci 172:254-264. doi:10.1111/j.1439-037X.1994.tb00176.x

Avice JC, Etienne P (2014) Leaf senescence and nitrogen remobilization efficiency in oilseed rape (Brassica napus L.). J Exp Bot 65(14): 3813-3824. doi:10.1093/jxb/eru177

Baggs EM, Rees RM, Smith KA, Vinten AJA (2000) Nitrous oxide emission from soils after incorporating crop residues. Soil Use Manag 16(2):82-87. doi:10.1111/j.1475-2743.2000.tb00179.x

Balint T, Rengel Z (2008) Nitrogen efficiency of canola genotypes varies between vegetative stage and grain maturity. Euphytica 164(2):421432. doi:10.1007/s10681-008-9693-6

Balint T, Rengel Z, Allen D (2008) Australian canola germplasm differs in nitrogen and sulfur efficiency. Crop Past Sci 60:262-270. doi:10. 1071/AR06255

Bänziger M, Betrán FJ, Lafitte HR (1997) Efficiency of high-nitrogen selection environments for improving maize for low-nitrogen target environments. Crop Sci 37:1103-1109. doi:10.2135/cropsci1997

Barraclough PB (1989) Root growth, macro-nutrient uptake dynamics and soil fertility requirements of a high-yielding winter oilseed rape crop. Plant Soil 119:59-70. doi:10.1007/BF02370269

Berrocoso J, Rojas O, Liu Y, Shoulders J, González-Vega J, Stein H (2015) Energy concentration and amino acid digestibility in highprotein canola meal, conventional canola meal, and soybean meal fed to growing pigs. J Anim Sci 93(5):2208-2217

Berry PM, Spink J, Foulkes MJ, White PJ (2010) The physiological basis of genotypic differences in nitrogen use efficiency in oilseed rape (Brassica napus L.). Field Crop Res 119(2-3):365-373. doi:10. 1016/j.fcr.2010.08.004

Billen G, Garnier J, Lassaletta L (2013) The nitrogen cascade from agricultural soils to the sea: modelling nitrogen transfers at regional watershed and global scales. Philos Trans R Soc Lond B Biol Sci 368(1621):20130123. doi:10.1098/rstb.2013.0123

Bissuel-Belaygue C, Allirand J M, Laperche A, Bidon M, Guichard S, leport L, Daniel L, Burban M, Duprix P, Franchet C, Rodrigues J, Richard-Molard C (2015) PERISCOPE : a new phenotyping experimental device for individual root and shoot investigations in reconstructed canopy until harvest, under field-like conditions, 14th International Rapeseed Congress, Saskatoon (Canada)

Bouchet A-S, Nesi N, Bissuel C, Bregeon M, Lariepe A, Navier H, Ribière N, Orsel M, Grezes-Besset B, Renard M, Laperche A (2014) Genetic control of yield and yield components in winter oilseed rape (Brassica napus L.) grown under nitrogen limitation. Euphytica 199(1-2):183-205. doi:10.1007/s10681-014-1130-4

Brancourt-Hulmel M, Heumez E, Pluchard P, Beghin D, Depatureaux C, Giraud A, Le Gouis J (2005) Indirect versus direct selection of winter wheat for low-input or high-input levels. Crop Sci 45(4): 1427. doi:10.2135/cropsci2003.0343

Bus A, Korber N, Snowdon RJ, Stich B (2011) Patterns of molecular variation in a species-wide germplasm set of Brassica napus. Theor Appl Genet 123(8):1413-1423. doi:10.1007/s00122-0111676-7

Chalhoub B, Denoeud F, Liu S, Parkin IA, Tang H, Wang X, Chiquet J, Belcram H, Tong C, Samans B, Correa M, Da Silva C, Just J, Falentin C, Koh CS, Le Clainche I, Bernard M, Bento P, Noel B, Labadie K, Alberti A, Charles M, Arnaud D, Guo H, Daviaud C, Alamery S, Jabbari K, Zhao M, Edger PP, Chelaifa H, Tack D, Lassalle G, Mestiri I, Schnel N, Le Paslier MC, Fan G, Renault V, Bayer PE, Golicz AA, Manoli S, Lee TH, Thi VH, Chalabi S, Hu Q, Fan C, Tollenaere R, Lu Y, Battail C, Shen J, Sidebottom CH, Wang X, Canaguier A, Chauveau A, Berard A, Deniot G, Guan M, Liu Z, Sun F, Lim YP, Lyons E, Town CD, Bancroft I, Wang X, Meng J, Ma J, Pires JC, King GJ, Brunel D, Delourme R, Renard M, Aury 
JM, Adams KL, Batley J, Snowdon RJ, Tost J, Edwards D, Zhou Y, Hua W, Sharpe AG, Paterson AH, Guan C, Wincker P (2014) Early allopolyploid evolution in the post-Neolithic Brassica napus oilseed genome. Science 345(6199):950-953. doi:10.1126/science. 1253435

Christen O, Sieling K (1993) The effect of different preceding crops on the development, growth and yield of winter barley. J Agron Crop Sci 171:114-123

Christen O, Sieling K, Hanus H (1992) The effect of different preceding crops on the development, growth and yield of winter wheat. Eur J Agron 1(1):21-28

Colnenne C, Meynard JM, Reau R, Justes E, Merrien A (1998) Determination of a critical dilution curve for winter oilseed rape. Ann Bot 81:311-317. doi:10.1006/anbo.1997.0557

Conant RT, Berdanier AB, Grace PR (2013) Patterns and trends in nitrogen use and nitrogen recovery efficiency in world agriculture. Glob Biogeochem Cycles 27(2):558-566. doi:10.1002/gbc.20053

Cormier F, Faure S, Dubreuil P, Heumez E, Beauchene K, Lafarge S, Praud S, Le Gouis J (2013) A multi-environmental study of recent breeding progress on nitrogen use efficiency in wheat (Triticum aestivum L.). Theor Appl Genet 126(12):3035-3048. doi:10.1007/ s00122-013-2191-9

Cramer N (1993) Umweltverträglichkeit der N-Versorgung des Rapses. 11: 4-7

Dejoux J-F, Recous S, Meynard J-M, Trinsoutrot I, Leterme P (2000) The fate of nitrogen from winter-frozen rapeseed leaves:mineralization, fluxes to the environment and uptake by rapeseed crop in spring. Plant Soil 218:257-272. doi:10.1023/A:1014934924819

Diepenbrock W (2000) Yield analysis of winter oilseed rape (Brassica napus L.): a review. Field Crop Res 67:35-49. doi:10.1016/S03784290(00)00082-4

Edwards D, Batley J, Snowdon RJ (2013) Accessing complex crop genomes with next-generation sequencing. Theor Appl Genet 126(1): 1-11. doi:10.1007/s00122-012-1964-x

Etienne P, Desclos M, Gou LL, Gombert J, Bonnefoy J, Maurel K, Dily FL, Ourry A, Avice J-C (2007) N-protein mobilisation associated with the leaf senescence process in oilseed rape is concomitant with the disappearance of trypsin inhibitor activity. Funct Plant Biol 34(10):895-906. doi:10.1093/jxb/erv031

Faes P, Deleu C, Ainouche A, Le Caherec F, Montes E, Clouet V, Gouraud AM, Albert B, Orsel M, Lassalle G, Leport L, Bouchereau A, Niogret MF (2015) Molecular evolution and transcriptional regulation of the oilseed rape proline dehydrogenase genes suggest distinct roles of proline catabolism during development. Planta 241(2):403-419. doi:10.1007/s00425-014-2189-9

Fageria N K, Baligar V C (2005) Enhancing Nitrogen Use Efficiency in crop plants. Adv Agron 88:97-185. doi:10.1016/S0065-2113(05) 88004-6

Fei H, McVetty PBE, Kevin Vessey J (2013) 13C and 15N partitioning among shoots, roots, and soil in Brassica napus genotypes varying in seed oil content potential. Biocatal Agric Biotechnol 2(2):143151. doi:10.1016/j.bcab.2013.02.001

Fiorani F, Schurr U (2013) Future scenarios for plant phenotyping. Annu Rev Plant Biol 64:267-291. doi:10.1146/annurev-arplant-050312120137

Fletcher RS, Mullen JL, Heiliger A, McKay JK (2014) QTL analysis of root morphology, flowering time, and yield reveals trade-offs in response to drought in Brassica napus. J Exp Bot 66(1):245-256. doi:10.1093/jxb/eru423

Food and Agriculture Organization of the United Nations (2013) FAOSTAT

Gammelvind LH, Schjoerring JK, Mogensen VO, Jensen CR, Bock JGH (1996) Photosynthesis in leaves and siliques of winter oilseed rape (Brassica napus L.). Plant Soil 186:227-236. doi:10.1007/ BF02415518
Garnett T, Conn V, Kaiser B N (2009) Root based approaches to improving nitrogen use efficiency in plants. Plant Cell Environ 32(9): 1272-1283. doi:10.1111/j.1365-3040.2009.02011.x

Gehringer A, Snowdon R, Spiller T, Basunanda P, Friedt W (2007) New oilseed rape (Brassica napus) hybrids with high levels of heterosis for seed yield under nutrient-poor conditions. Breed Sci 57:315320. doi:10.1270/jsbbs. 57.315

Girondé A, Etienne P, Trouverie J, Bouchereau A, Le Cahérec F, Leport L, Orsel M, Niogret M-F, Nesi N, Carole D, Soulay F, MasclauxDaubresse C, Avice J-C (2015) The contrasting N management of two oilseed rape genotypes reveals the mechanisms of proteolysis associated with leaf $\mathrm{N}$ remobilization and the respective contributions of leaves and stems to $\mathrm{N}$ storage and remobilization during seed filling. BMC Plant Biol 15(1):59. doi:10.1186/s12870-0150437-1

Gombert J, Etienne P, Ourry A, Le Dily F (2006) The expression patterns of SAG12/Cab genes reveal the spatial and temporal progression of leaf senescence in Brassica napus L. with sensitivity to the environment. J Exp Bot 57(9):1949-1956. doi:10.1093/jxb/erj142

Good AG, Shrawat AK, Muench DG (2004) Can less yield more? Is reducing nutrient input into the environment compatible with maintaining crop production? Trends Plant Sci 9(12):597-605. doi:10. 1016/j.tplants.2004.10.008

Good AG, Johnson SJ, De Pauw M, Carroll RT, Savidov N, Vidmar J, Lu Z, Taylor G, Stroeher V (2007) Engineering nitrogen use efficiency with alanine aminotransferase. Can J Bot 85(3):252-262. doi:10. 1139/b07-019

Gregersen PL, Culetic A, Boschian L, Krupinska K (2013) Plant senescence and crop productivity. Plant Mol Biol 82(6):603-622. doi:10. 1007/s11103-013-0013-8

Gül MK (2002) QTL mapping and analysis of QTL x nitrogen interactions for some yield components in Brassica napus L. Turk J Agric For 27:71-76

Habekotté B (1993) Quantitative analysis of pod formation, seed set and seed filling in winter oilseed rape (Brassica napus L.) under field conditions. Field Crop Res 35:21-33. doi:10.1016/0378-4290(93) 90133-8

Habekotté B (1997) Options for increasing seed yield of winter oilseed rape (Brassica napus L.): a simulation study. Field Crop Res 54: 109-126. doi:10.1016/S0378-4290(97)00041-5

Han M, Okamoto M, Beatty PH, Rothstein SJ, Good AG (2015) The genetics of nitrogen use efficiency in crop plants. Annu Rev Genet 13(27). doi:10.1146/annurev-genet-112414-055037

Hasan M, Seyis F, Badani AG, Pons-Kühnemann J, Friedt W, Lühs W, Snowdon RJ (2005) Analysis of genetic diversity in the Brassica napus L. gene pool using SSR markers. Genet Resour Crop Evol 53(4):793-802. doi:10.1007/s10722-004-5541-2

Hatzig SV, Frisch M, Breuer F, Nesi N, Ducournau S, Wagner MH, Leckband G, Abbadi A, Snowdon RJ (2015) Genome-wide association mapping unravels the genetic control of seed germination and vigor in Brassica napus. Front Plant Sci 6:221. doi:10.3389/fpls. 2015.00221

Hirel B, Le Gouis J, Ney B, Gallais A (2007) The challenge of improving nitrogen use efficiency in crop plants: towards a more central role for genetic variability and quantitative genetics within integrated approaches. J Exp Bot 58(9): 2369-2387. doi:10.1093/jxb/erm097

Hocking PJ, Randall PJ, DeMarco D (1997) The response of dryland canola to nitrogen fertilizer: partitioning and mobilization of dry matter and nitrogen, and nitrogen effects on yield components. Field Crop Res 54:201-220. doi:10.1016/S0378-4290(97)00049-X

Hohmann, M., Stahl, A., Rudloff, J., Wittkop, B., and Snowdon, R. J. (2016) Not a load of rubbish: simulated field trials in large-scale containers. Plant, Cell \& Environ, doi:10.1111/pce.12737

Jan HU, Abbadi A, Lucke S, Nichols RA, Snowdon RJ (2016) Genomic prediction of testcross performance in canola (Brassica napus). PLoS One 11(1):e0147769. doi:10.1371/journal.pone.0147769 
Kage H (1997) Is low rooting density of faba beans a cause of high residual nitrate content of soil at harvest? Plant Soil 190(1):47-60. doi:10.1023/A:1004250905262

Kaiser E-A, Kohrs K, Kücke M, Schnug E, Heinemeyer O, Munch JC (1998) Nitrous oxide release from arable soil: importance of N-fertilization, crops and temporal variation. Soil Biol Biochem 30(12): 1553-1563. doi:10.1016/S0038-0717(98)00036-4

Kamh M, Wiesler F, Ulas A, Horst WJ (2005) Root growth and N-uptake activity of oilseed rape (Brassica napus L.) cultivars differing in nitrogen efficiency. J Plant Nutr Soil Sci 168:130-137. doi:10. 1002/jpln.200421453

Karamanos RE, Goh TB, Poisson DP (2005) Nitrogen, phosphorus, and sulfur fertility of hybrid canola. J Plant Nutr 28(7):1145-1161. doi: 10.1081/PLN-200063138

Karamanos RE, Goh TB, Flaten DN (2006) Nitrogen and sulphur fertilizer management for growing canola on sulphur sufficient soils. Can J Plant Sci 87:201-210. doi:10.4141/P06-133

Kebede B, Thiagarajah M, Zimmerli C, Rahman MH (2010) Improvement of open-pollinated spring rapeseed (Brassica napus L.) through introgression of genetic diversity from winter rapeseed. Crop Sci 50(4):1236. doi:10.2135/cropsci2009.06.0352

Kessel B, Schierholt A, Becker HC (2012) Nitrogen use efficiency in a genetically diverse set of winter oilseed rape (Brassica napus L.). Crop Sci 52(6):2546. doi:10.2135/cropsci2012.02.0134

Koeslin-Findeklee F, Meyer A, Girke A, Beckmann K, Horst WJ (2014) The superior nitrogen efficiency of winter oilseed rape (Brassica napus L.) hybrids is not related to delayed nitrogen starvationinduced leaf senescence. Plant Soil 384(1-2):347-362. doi:10. 1007/s11104-014-2212-8

Koeslin-Findeklee F, Becker M, Graaff EVD, Roitsch T, Horst W (2015a) Differences between winter oilseed rape (Brassica napus L.) cultivars in nitrogen starvation-induced leaf senescence are governed by leaf-inherent rather than root-derived signals. J Exp Bot 66(13): 3669-3681. doi:10.1093/jxb/erv170

Koeslin-Findeklee F, Rizi VS, Becker MA, Parra-Londono S, Arif M, Balazadeh S, Mueller-Roeber B, Kunze R, Horst WJ (2015b) Transcriptomic analysis of nitrogen starvation- and cultivarspecific leaf senescence in winter oilseed rape (Brassica napus L.). Plant Sci 233:174-185. doi:10.1016/j.plantsci.2014.11.018

Krouk G, Lacombe B, Bielach A, Perrine-Walker F, Malinska K, Mounier E, Hoyerova K, Tillard P, Leon S, Ljung K, Zazimalova E, Benkova E, Nacry P, Gojon A (2010) Nitrate-regulated auxin transport by NRT1.1 defines a mechanism for nutrient sensing in plants. Dev Cell 18(6):927-937. doi:10.1016/j.devcel.2010.05.008

Lassaletta L, Billen G, Grizzetti B, Anglade J, Garnier J (2014) 50 year trends in nitrogen use efficiency of world cropping systems: the relationship between yield and nitrogen input to cropland. Environ Res Lett 9(10):105011. doi:10.1088/1748-9326/9/10/105011

Le Deunff E, Malagoli P (2014) An updated model for nitrate uptake modelling in plants. I. Functional component: cross-combination of flow-force interpretation of nitrate uptake isotherms, and environmental and in planta regulation of nitrate influx. Ann Bot 113(6): 991-1005. doi:10.1093/aob/mcu021

Lee B-R, Jin Y-L, Park S-H, Zaman R, Zhang Q, Avice J-C, Ourry A, Kim T-H (2015) Genotypic variation in N uptake and assimilation estimated by $15 \mathrm{~N}$ tracing in water deficit-stressed Brassica napus. Environ Exp Bot 109:73-79. doi:10.1016/j.envexpbot.2014.08.004

Lemaire G, Salette J, Sigogne M, Terrasson J-P (1984) Relation entre dynamique de croissance et dynamique de prélèvement d'azote pour un peuplement de graminées fourragères. I.- Etude de l'effet du milieu. Agronomie 4(5):423-430. doi:10.1051/agro:19840503

Little DY, Rao H, Oliva S, Daniel-Vedele F, Krapp A, Malamy JE (2005) The putative high-affinity nitrate transporter NRT2.1 represses lateral root initiation in response to nutritional cues. Proc Natl Acad Sci U S A 102(38):13693-13698. doi:10.1073/pnas.0504219102
Lynch JP (2014) Root phenes that reduce the metabolic costs of soil exploration: opportunities for 21st century agriculture. Plant Cell Environ. doi:10.1111/pce.12451

Malagoli P, Laine P, Rossato L, Ourry A (2005a) Dynamics of nitrogen uptake and mobilization in field-grown winter oilseed rape (Brassica napus) from stem extension to harvest: I. Global N flows between vegetative and reproductive tissues in relation to leaf fall and their residual N. Ann Bot 95(5):853-861. doi:10.1093/aob/ mci091

Malagoli P, Laine P, Rossato L, Ourry A (2005b) Dynamics of nitrogen uptake and mobilization in field-grown winter oilseed rape (Brassica napus) from stem extension to harvest. II. An $15 \mathrm{~N}$ labelling-based simulation model of $\mathrm{N}$ partitioning between vegetative and reproductive tissues. Ann Bot 95(7):1187-1198. doi:10. 1093/aob/mci131

Malamy JE, Ryan KS (2001) Environmental regulation of lateral root initiation in Arabidopsis. Plant Physiol 127(3):899-909. doi:10. 1104/pp.010406

Masclaux-Daubresse C, Daniel-Vedele F, Dechorgnat J, Chardon F, Gaufichon L, Suzuki A (2010) Nitrogen uptake, assimilation and remobilization in plants: challenges for sustainable and productive agriculture. Ann Bot 105(7):1141-1157. doi:10.1093/aob/mcq028

Miersch S (2014) Nitrogen efficiency in semi-dwarf and normal hybrids of oilseed rape. Faculty of Agricultural Sciences, Georg-AugustUniversität Göttingen, Göttingen

Miller AJ, Fan X, Orsel M, Smith SJ, Wells DM (2007) Nitrate transport and signalling. J Exp Bot 58(9):2297-2306. doi:10.1093/jxb/ erm066

Miro B (2010) Identification of traits for nitrogen use efficiency in oilseed rape (Brassica napus L.). School of Agriculture Food and Rural Development, Newcastle University, Newcastle

Moll RH, Kamprath EJ, Jackson WA (1982) Analysis and interpretation of factors which contribute to efficiency of nitrogen utilization. Agron J 74:562-564. doi:10.2134/agronj1982. $00021962007400030037 \mathrm{x}$

Muñoz-Huerta RF, Guevara-Gonzalez RG, Contreras-Medina LM, Torres-Pacheco I, Prado-Olivarez J, Ocampo-Velazquez RV (2013) A review of methods for sensing the nitrogen status in plants: advantages, disadvantages and recent advances. Sensors 13(8):1082310843. doi:10.3390/s130810823

Musse M, De Franceschi L, Cambert M, Sorin C, Le Caherec F, Burel A, Bouchereau A, Mariette F, Leport L (2013) Structural changes in senescing oilseed rape leaves at tissue and subcellular levels monitored by nuclear magnetic resonance relaxometry through water status. Plant Physiol 163(1):392-406. doi:10.1104/pp.113.223123

Noh Y, Amasino R (1999) Regulation of developmental senescence is conserved between Arabidopsis and Brassica napus. Plant Mol Biol 41(2):195-206. doi:10.1023/A:1006389803990

Nyikako J, Schierholt A, Kessel B, Becker HC (2014) Genetic variation in nitrogen uptake and utilization efficiency in a segregating $\mathrm{DH}$ population of winter oilseed rape. Euphytica 199(1-2):3-11. doi: 10.1007/s10681-014-1201-6

Orsel M, Moison M, Clouet V, Thomas J, Leprince F, Canoy AS, Just J, Chalhoub B, Masclaux-Daubresse C (2014) Sixteen cytosolic glutamine synthetase genes identified in the Brassica napus L. genome are differentially regulated depending on nitrogen regimes and leaf senescence. J Exp Bot 65(14):3927-3947. doi:10.1093/jxb/eru041

Parnaudeau V, Jeuffroy MH, Machet JM, Reau R, Bissuel C, Eveillard P (2009) Methods for determining the nitrogen fertiliser requirements of some major arable crops in France. International Fertiliser Society, Cambridge, pp 1-26

Postma JA, Schurr U, Fiorani F (2014) Dynamic root growth and architecture responses to limiting nutrient availability: linking physiological models and experimentation. Biotechnol Adv 32(1):53-65. doi: 10.1016/j.biotechadv.2013.08.019 
Qian W, Sass O, Meng J, Li M, Frauen M, Jung C (2007) Heterotic patterns in rapeseed (Brassica napus L.): I. Crosses between spring and Chinese semi-winter lines. Theor Appl Genet 115(1):27-34. doi: $10.1007 / \mathrm{s} 00122-007-0537-\mathrm{x}$

Rahman M, McClean P (2013) Genetic analysis on flowering time and root system in Brassica napus L. Crop Sci 53(1):141. doi:10.2135/ cropsci2012.02.0095

Rathke GW, Christen O, Diepenbrock W (2005) Effects of nitrogen source and rate on productivity and quality of winter oilseed rape (Brassica napus L.) grown in different crop rotations. Field Crop Res 94(2-3):103-113. doi:10.1016/j.fcr.2004.11.010

Rathke GW, Behrens T, Diepenbrock W (2006) Integrated nitrogen management strategies to improve seed yield, oil content and nitrogen efficiency of winter oilseed rape (Brassica napus L.): a review. Agric Ecosyst Environ 117(2-3):80-108. doi:10.1016/j.agee.2006. 04.006

Remans T, Nacry P, Pervent M, Filleur S, Diatloff E, Mounier E, Tillard P, Forde BG, Gojon A (2006a) The Arabidopsis NRT1.1 transporter participates in the signaling pathway triggering root colonization of nitrate-rich patches. Proc Natl Acad Sci U S A 103(50):1920619211. doi:10.1073/pnas.0605275103

Remans T, Nacry P, Pervent M, Girin T, Tillard P, Lepetit M, Gojon A (2006b) A central role for the nitrate transporter NRT2.1 in the integrated morphological and physiological responses of the root system to nitrogen limitation in Arabidopsis. Plant Physiol 140(3): 909-921. doi:10.1104/pp.105.075721

Rossato L, Lainé P, Ourry A (2001) Nitrogen storage and remobilization in Brassica napus L. during the growth cycle: nitrogen fluxes within the plant and changes in soluble protein patterns. J Exp Bot 52(361): 1655-1663. doi:10.1016/j.fcr.2015.04.005

Samans B, Snowdon RJ, Scholz U, Weise S, von Wiren N, Ordon F, Nagel K, Fiorani F, Schurr U, Léon J, Li J, Stich B, Becker H, Hinze M, Brummermann H, Breuer F, Duchscherer P, Kaiser J, Abel S, Stelling D, Micic Z, Ahlemeyer J, Wolf M, Abbadi A, Leckband G (2013) PreBreed-Yield: population genomics resources for nested association mapping and precision breeding in winter oilseed rape. International Plant and Animal Genome Conference XXI 2013, San Diego

Schulte auf'm Erley G, Wijaya K-A, Ulas A, Becker H, Wiesler F, Horst WJ (2007) Leaf senescence and $\mathrm{N}$ uptake parameters as selection traits for nitrogen efficiency of oilseed rape cultivars. Physiol Plant 130(4):519-531. doi:10.1111/j.1399-3054.2007.00921.x

Schulte auf'm Erley G, Behrens T, Ulas A, Wiesler F, Horst WJ (2011) Agronomic traits contributing to nitrogen efficiency of winter oilseed rape cultivars. Field Crop Res 124(1):114-123. doi:10.1016/j. fcr.2011.06.009

Seyis F, Snowdon RJ, Lühs W, Friedt W (2003) Molecular characterization of novel resynthesized rapeseed (Brassica napus) lines and analysis of their genetic diversity in comparison with spring rapeseed cultivars. Plant Breed 122:473-478. doi:10.1111/j.1439-0523. 2003.00859.x

Shi L, Shi T, Broadley MR, White PJ, Long Y, Meng J, Xu F, Hammond JP (2012) High-throughput root phenotyping screens identify genetic loci associated with root architectural traits in Brassica napus under contrasting phosphate availabilities. Ann Bot 112(2):381389. doi:10.1093/aob/mcs 245

Snowdon RJ, Abbadi A, Kox T, Schmutzer T, Leckband G (2015) Heterotic haplotype capture: precision breeding for hybrid performance. Trends Plant Sci 20(7):410-413. doi:10.1016/j.tplants.2015. 04.013

Sorin C, Musse M, Mariette F, Bouchereau A, Leport L (2015) Assessment of nutrient remobilization through structural changes of palisade and spongy parenchyma in oilseed rape leaves during senescence. Planta 241(2):333-346. doi:10.1007/s00425-014-2182-3

Sorin C, Leport L, Cambert M, Bouchereau A, Mariette F, Musse M (2016) Nitrogen deficiency impacts on leaf cell and tissue structure with consequences for senescence associated processes in Brassica napus. Botanical Studies in press.

Spano G (2003) Physiological characterization of 'stay green' mutants in durum wheat. J Exp Bot 54(386):1415-1420. doi:10.1093/jxb/ $\operatorname{erg} 150$

Stahl A, Friedt W, Wittkop B, Snowdon RJ (2015) Complementary diversity for nitrogen uptake and utilisation efficiency reveals broad potential for increased sustainability of oilseed rape production. Plant Soil 400(1-2):245-262. doi:10.1007/s11104-015-2726-8

Sullivan WM, Jiang Z, Hull RJ (2000) Root morphology and its relationship with nitrate uptake in kentucky bluegrass. Crop Sci 40(3):765. doi:10.2135/cropsci2000.403765x

Svečnjak Z, Rengel Z (2005) Canola cultivars differ in nitrogen utilization efficiency at vegetative stage. Field Crop Res 97(2-3):221-226. doi:10.1016/j.fcr.2005.10.001

Svečnjak Z, Rengel Z (2006) Nitrogen utilization efficiency in canola cultivars at grain harvest. Plant Soil 283(1-2):299-307. doi:10. 1007/s11104-006-0020-5

Sylvester-Bradley R, Kindred DR (2009) Analysing nitrogen responses of cereals to prioritize routes to the improvement of nitrogen use efficiency. J Exp Bot 60(7):1939-1951. doi:10.1093/jxb/erp116

Taylor L, Nunes-Nesi A, Parsley K, Leiss A, Leach G, Coates S, Wingler A, Fernie AR, Hibberd JM (2010) Cytosolic pyruvate, orthophosphate dikinase functions in nitrogen remobilization during leaf senescence and limits individual seed growth and nitrogen content. Plant J 62(4):641-652. doi:10.1111/j.1365-313X.2010.04179.x

Thomas H, Howarth CJ (2000) Five ways to stay green. J Exp Bot 51: 329-337. doi:10.1093/jexbot/51.suppl_1.329

Thomas H, Ougham H (2014) The stay-green trait. J Exp Bot 65(14): 3889-3900. doi:10.1093/jxb/eru037

Thomas CL, Graham NS, Hayden R, Meacham MC, Neugebauer K, Nightingale M, Dupuy LX, Hammond JP, White PJ, Broadley MR (2016) High-throughput phenotyping (HTP) identifies seedling root traits linked to variation in seed yield and nutrient capture in fieldgrown oilseed rape (Brassica napus L.). Ann Bot. doi:10.1093/aob/ mew046

Thurling N (1991) Application of the ideotype concept in breeding for higher yield in the oilseed brassicas. Field Crop Res 26:201-219. doi:10.1016/0378-4290(91)90036-U

Tilman D, Cassman KG, Matson PA, Naylor R, Polasky S (2002) Agricultural sustainability and intensive production practices. Nature 418(6898):671-677

Tilsner J, Kassner N, Struck C, Lohaus G (2005) Amino acid contents and transport in oilseed rape (Brassica napus L.) under different nitrogen conditions. Planta 221(3):328-338. doi:10.1007/s00425-004-14468

Tranbarger TJ, Al-ghazi Y, Muller B, Serve BTdl, Doumas P, Touraine B (2003) Transcription factor genes with expression correlated to nitrate-related root plasticity of Arabidopsis thaliana. Plant Cell Environ 26(3):459-469. doi:10.1046/j.1365-3040.2003.00977.x

U N (1935) Genome analysis in Brassica with special reference to the experimental formation of $B$. napus and peculiar mode of fertilization. Jpn J Bot 7:389-452

Udall JA, Quijada PA, Polewicz H, Vogelzang R, Osborn TC (2004) Phenotypic effects of introgressing chinese winter and resynthesized Brassica napus L. germplasm into hybrid spring canola. Crop Sci 44:1990-1996

Ulas A, Behrens T, Wiesler F, Horst WJ, Schulte auf'm Erley G (2013) Does genotypic variation in nitrogen remobilisation efficiency contribute to nitrogen efficiency of winter oilseed-rape cultivars (Brassica napus L.)? Plant Soil 371:463-471. doi:10.1007/s11104013-1688-y

van der Heijden G, Song Y, Horgan G, Polder G, Dieleman A, Bink M, Palloix A, van Eeuwijk F, Glasbey C (2012) SPICY: towards automated phenotyping of large pepper plants in the greenhouse. Funct Plant Biol 39(11):870-877. doi:10.1071/FP12019 
Vincourt P (2014) Research fields, challenges and opportunities in European oilseed crops breeding. OCL 21(6):D602. doi:10.1051/ ocl $/ 2014043$

Voss-Fels K, Snowdon RJ (2015) Understanding and utilizing crop genome diversity via high-resolution genotyping. Plant Biotechnol J. doi:10.1111/pbi.12456

Wang G, Ding G, Li L, Cai H, Ye X, Zou J, Xu F (2014) Identification and characterization of improved nitrogen efficiency in interspecific hybridized new-type Brassica napus. Ann Bot 114(3):549-559. doi: 10.1093/aob/mcu135

White PJ, George TS, Dupuy LX, Karley AJ, Valentine TA, Wiesel L, Wishart J (2013) Root traits for infertile soils. Front Plant Sci 4:193. doi:10.3389/fpls.2013.00193

Wiesler F, Horst WJ (1994) Root growth and nitrate utilization of maize cultivars under field conditions. Plant Soil 163(2):267-277. doi:10. 1007/BF00007976

Wiesler F, Behrens T, Horst WJ (2001) Nitrogen efficiency of contrasting rape ideotypes, plant nutrition. Springer, Netherlands, pp 60-61

Wood CW, Reeves DW, Duffield RR, Edmistena KL (1992) Field chlorophyll measurements for evaluation of corn nitrogen status. J Plant Nutr 15(4):487-500

Würschum T, Abel S, Zhao Y, Léon J (2013) Potential of genomic selection in rapeseed (Brassica napus L.) breeding. Plant Breed 133(1): 45-51. doi:10.1111/pbr.12137

Xu G, Fan X, Miller A J (2012) Plant nitrogen assimilation and use efficiency. Annu Rev Plant Biol 63:153-182. doi:10.1146/ annurev-arplant-042811-105532
Yang M, Ding G, Shi L, Feng J, Xu F, Meng J (2010) Quantitative trait loci for root morphology in response to low phosphorus stress in Brassica napus. Theor Appl Genet 121(1):181-193. doi:10.1007/ s00122-010-1301-1

Yau SK, Thurling N (1986) Variation in nitrogen response among spring rape (Brassica napus) cultivars and its relationship to nitrogen uptake and utilization. Field Crop Res 16(2):139-155. doi:10.1016/ 0378-4290(87)90004-9

Yea X, Honga J, Shiab L, Xu F (2010) Adaptability mechanism of nitrogen-efficient germplasm of natural variation to low nitrogen stress in Brassica napus. J Plant Nutr 33(13):2028-2040. doi:10. 1080/01904167.2010.512211

Zhang H, Forde BG (1998) An Arabidopsis MADS box gene that controls nutrient-induced changes in root architecture. Science 279(5349):407-409. doi:10.1126/science.279.5349.407

Zhang H, Forde BG (2000) Regulation of Arabidopsis root development by nitrate availability. J Exp Bot 51(342):51-59. doi:10.1093/ jexbot $/ 51.342 .51$

Zhao Y, Wang ML (2004) Inheritance and agronomic performance of an apetalous flower mutant in Brassica napus L. Euphytica 137:381386. doi:10.1023/B:EUPH.0000040522.37048.7a

Zhou Q-H, Fu D-H, Mason AS, Zeng Y-J, Zhao C-X, Huang Y-J (2014) In silico integration of quantitative trait loci for seed yield and yieldrelated traits in Brassica napus. Mol Breed 33(4):881-894. doi:10. 1007/s11032-013-0002-2 